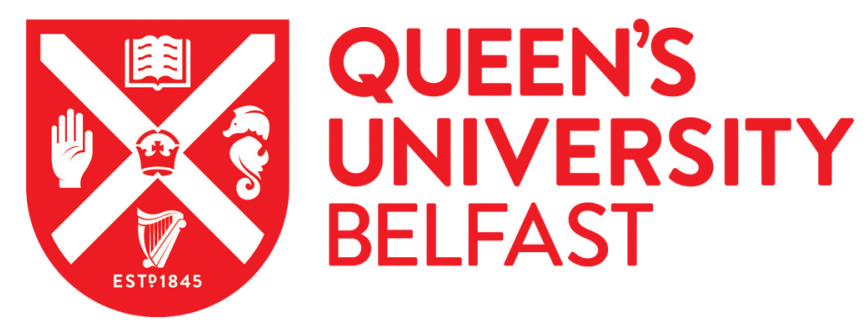

\title{
Geology and geochemistry-based metallogenic exploration model for the eastern Tethys Himalayan metallogenic belt, Tibet
}

\author{
Zheng, W., Liu, B., McKinley, J., Cooper, M. R., \& Wang, L. (2021). Geology and geochemistry-based \\ metallogenic exploration model for the eastern Tethys Himalayan metallogenic belt, Tibet. Journal of \\ Geochemical Exploration, 224, [106743]. https://doi.org/10.1016/j.gexplo.2021.106743
}

Published in:

Journal of Geochemical Exploration

\section{Document Version:}

Peer reviewed version

Queen's University Belfast - Research Portal:

Link to publication record in Queen's University Belfast Research Portal

\section{Publisher rights}

Copyright 2021 Elsevier B.V.

This manuscript is distributed under a Creative Commons Attribution-NonCommercial-NoDerivs License

(https://creativecommons.org/licenses/by-nc-nd/4.0/), which permits distribution and reproduction for non-commercial purposes, provided the author and source are cited.

\section{General rights}

Copyright for the publications made accessible via the Queen's University Belfast Research Portal is retained by the author(s) and / or other copyright owners and it is a condition of accessing these publications that users recognise and abide by the legal requirements associated with these rights.

Take down policy

The Research Portal is Queen's institutional repository that provides access to Queen's research output. Every effort has been made to ensure that content in the Research Portal does not infringe any person's rights, or applicable UK laws. If you discover content in the Research Portal that you believe breaches copyright or violates any law, please contact openaccess@qub.ac.uk. 


\section{Journal of Geochemical Exploration \\ Metallogenic prediction model based on geological conditions and geochemical anomalies of CoDA, eastern of the Tethys Himalayan metallogenic belt, China --Manuscript Draft--}

\begin{tabular}{|c|c|}
\hline Manuscript Number: & \\
\hline Article Type: & Research Paper \\
\hline Keywords: & $\begin{array}{l}\text { Geology; Compositional data analysis; Regional metallogeny; Metallogenic prediction } \\
\text { model; Tethys Himalaya }\end{array}$ \\
\hline Corresponding Author: & $\begin{array}{l}\text { Bingli Liu, Ph. D } \\
\text { Geomathematics Key Laboratory of Sichuan Province, Chengdu University of } \\
\text { Thechnology; UNESCO International Center on Global-scale Geochemistry } \\
\text { Chengdu, Sichuan CHINA }\end{array}$ \\
\hline First Author: & Wenbao Zheng \\
\hline Order of Authors: & Wenbao Zheng \\
\hline & Bingli Liu, Ph. D \\
\hline & Jennifer M. McKinley \\
\hline & Mark R. Cooper \\
\hline Abstract: & $\begin{array}{l}\text { The Tethys Himalaya is the fourth metallogenic belt discovered in the Tibet Plateau } \\
\text { and is mainly composed of chromite, Au and Sb-polymetallic deposits. The belt has } \\
\text { experienced a series of complex tectonic evolution-magmatism events, such as the } \\
\text { break-up, subduction, collision, detachment and obduction of the East Gondwana } \\
\text { continent, which has produced unique mineralization. Limited understanding remains in } \\
\text { some areas, such as the confusion of genetic types of deposits, the unclear } \\
\text { relationship between tectonic evolution-magmatism and regional mineralization, and } \\
\text { as a result there is no clear direction for further geological exploration at most of the } \\
\text { mineralization occurrences. Based on the long-term research and exploration work in } \\
\text { this area, as well as investigation of the metallogenic regularity of various deposits in } \\
\text { surrounding regions, three main deposit types (ophiolite chromite deposit, orogenic Au } \\
\text { deposit and hydrothermal-vein Sb-polymetallic deposit) and two types of predicted } \\
\text { deposits (island arc type porphyry Cu-Au deposit and Sn deposit related to } \\
\text { leucogranite) are proposed. This study summaries the relationship between tectonic } \\
\text { evolution-magmatism and mineralization, and establishes the time-space framework } \\
\text { of regional mineralization in eastern of the Tethys Himalayan metallogenic belt. }\end{array}$ \\
\hline Suggested Reviewers: & $\begin{array}{l}\text { Xueqiu Wang, Ph.D } \\
\text { Chinese Academy of Geological Sciences Institute of Geophysical and Geochemical } \\
\text { Exploration; UNESCO } \\
\text { wangxueqiu@igge.cn }\end{array}$ \\
\hline & $\begin{array}{l}\text { Keyan Xiao } \\
\text { CAGS: Chinese Academy of Geological Sciences } \\
\text { kyanxiao@sohu.com }\end{array}$ \\
\hline & $\begin{array}{l}\text { Ray Scanlon } \\
\text { r.scanlon@gsi.ie }\end{array}$ \\
\hline & $\begin{array}{l}\text { Eric Grunsky } \\
\text { egrunsky@gmail.com }\end{array}$ \\
\hline & $\begin{array}{l}\text { Antonella Buccianti } \\
\text { antonella.buccianti@unifi.it }\end{array}$ \\
\hline
\end{tabular}




\title{
Metallogenic prediction model based on geological conditions and geochemical anomalies of CoDA, eastern of the Tethys Himalayan metallogenic belt, China
}

\author{
Wenbao Zheng, ${ }^{\mathrm{a}, \mathrm{b}}$, Bingli Liu ${ }^{\mathrm{c} *}$, Jennifer M. McKinley ${ }^{\mathrm{d}}$, Mark R. Cooper ${ }^{\mathrm{e}}$, Bin Lin ${ }^{\mathrm{a}}$, \\ Shuai Ding ${ }^{\mathrm{b}}$, Qiufeng Leng ${ }^{\mathrm{b}}, \mathrm{Lu}^{\mathrm{Wang}}{ }^{\mathrm{c}}$
}

${ }^{a}$ MNR Key Laboratory of Metallogeny and Mineral Assessment, Institute of Mineral Resources, CAGS, Beijing 100037, China

${ }^{\mathrm{b}}$ Shanghai Pengyan Geological Science and Technology Co., LTD, Shanghai 202150, China

${ }^{\mathrm{c}}$ Geomathematics Key Laboratory of Sichuan Province (Chengdu University of Technology), Chengdu 610059, China

${ }^{\mathrm{d}}$ School of Natural and Built Environment, Queen's University Belfast, BT7 1NN, UK

${ }^{\mathrm{e}}$ Geological Survey of Northern Ireland, Dundonald House, Upper Newtownards Road, Belfast, BT4 3SB, UK

${ }^{\mathrm{f}}$ Faculty of Geosciences and Environmental Engineering, Southwest Jiaotong University, Chengdu 611756, China

\begin{abstract}
The Tethys Himalaya is the fourth metallogenic belt discovered in the Tibet Plateau and is mainly composed of chromite, Au and Sb-polymetallic deposits. The belt has experienced a series of complex tectonic evolution-magmatism events, such as the break-up, subduction, collision, detachment and obduction of the East Gondwana continent, which has produced unique mineralization. Limited understanding remains in some areas, such as the confusion of genetic types of deposits, the unclear relationship between tectonic evolution-magmatism and regional mineralization, and as a result there is no clear direction for further geological exploration at most of the mineralization occurrences. Based on the long-term research and exploration work in this area, as well as investigation of the metallogenic regularity of various deposits in surrounding regions, three main deposit types (ophiolite chromite deposit, orogenic $\mathrm{Au}$ deposit and hydrothermal-vein Sb-polymetallic deposit) and two types of predicted deposits (island arc type porphyry $\mathrm{Cu}-\mathrm{Au}$ deposit and $\mathrm{Sn}$ deposit related to leucogranite) are proposed. This study summaries the relationship between tectonic evolution-magmatism and mineralization, and establishes the time-space framework of regional mineralization in eastern of the Tethys Himalayan metallogenic belt.

Based on improved knowledge of relative geochemical signatures obtained from
\end{abstract}

${ }^{*}$ Corresponding author: Bingli Liu

Address: No.1, Dongsan Road, Chenghua District, Chengdu City, Sichuan Province, China

Email: liubingli-82@163.com; Tel: +86 18030617735 
compositional data analysis (CoDA) combined with geological knowledge, nine groups of compositional balances have been obtained, identifying sedimentary strata, accretionary wedge structure, leucogranite, mafic-ultramafic rocks, chromite mineralization, Au mineralization and Sb-polymetallic mineralization. This study establishes the metallogenic prediction model, and predicts the regional exploration direction through geological information and identification of geochemical anomalies. It is suggested that the ophiolitic belt, with a length of $50 \mathrm{~km}$ in the Nedong area, is very conducive to the exploration of chromite deposits; the $\mathrm{Au}-\mathrm{Cu}-\mathrm{Mo}$ high value anomaly area in Qonggyai-Qusum area has the prospect of exploration of orogenic Au deposits; the $\mathrm{Au}-\mathrm{Cu}-\mathrm{Mo}$ high value anomaly area in Nianzha, Sangri and Gyaca areas is the key exploration target of "Xiongcun-type" island arc type porphyry $\mathrm{Cu}-\mathrm{Au}$ deposit; the deep direciton of Sb-polymetallic deposit and the inner-outer contact zone of Lhozhag and Cuonadong leucogranite may be the important breakthrough of $\mathrm{Sn}(\mathrm{Be}-\mathrm{U})$ deposit.

Keywords: Geology; Compositional data analysis; Regional metallogeny; Metallogenic prediction model; Tethys Himalaya

\section{Introduction}

The Tethys Himalayan metallogenic belt is located between the Indus-Yarlung Zangbo suture zone and the Southern Tibet Detachment System fault (Fig.1a). It is an important part of the IndoEurasian continent collisional foreland fold-thrust belt, and it is also another $\mathrm{Cr}$, $\mathrm{Au}$ and Sb-polymetallic metallogenic belt discovered in the Tibet Plateau after the Sanjiang $\mathrm{Cu}(\mathrm{Mo})$, Gangdese $\mathrm{Cu}-\mathrm{Mo}$ and Bangong-Nujiang $\mathrm{Cu}-\mathrm{Au}$ metallogenic belt. The resources of chromite in the Luobusha-Xiangkashan-Kangjinla area in the belt account for more than $40 \%$ of the total amount of chromite in China (Fig. 1b; Yang et al., 2018), and that, in the Zhaxikang-KeyueYufeng area, the metal resources of $\mathrm{Sb}$ have been proved to be more than 200,000 tons, and $\mathrm{Pb}+$ $\mathrm{Zn}$ has reached 2 million tons (Fig. 1b; Wang et al., 2012). In addition, a large number of medium-sized Au deposits have been found in the area (Fig. 1b; Yang et al., 2009; Zhai et al., 2014). The special deposit types and element assemblages in the Tethys Himalayan belt are closely related to the complex tectonic evolution-magmatic activities. However, the metallogenesis, regional metallogenic regularity and metallogenic prediction of the deposits in this area are still at a low level. For example, there is a dispute between orogenic-type and carlin-type deposits for gold deposits (Yang et al., 2006; Zhai et al., 2014; Zheng et al., 2007), and between SEDEX-type and hydrothermal-vein-type for Sb-polymetallic deposits (Wang et al., 2012; Zheng et al., 2012). Therefore, the continuous summary of regional metallogenic regularity is of great significance for the research and exploration of the deposit.

In terms of regional exploration work, in addition to continuous theoretical research, geochemical methods are also very important. In particular, geochemical exploration is essential prior to other exploration methods in this shallow covered area of Tibet Plateau, which has been confirmed in most of the discovered deposits (Cheng et al., 2001; Du et al., 2001; Liu et al., 2018; Yang et al., 2017). However, the anomalies obtained by different geochemical data processing methods are often quite different. The elemental associations used by traditional geochemical processing method is mainly composed of a few ore-forming elements, and the anomalies of several single elements obtained are mainly used for interpretation of mineralization, and the 
anomalies are often scattered (Sun et al., 2016; Zheng et al., 2014). The use of Compositional data analysis (CoDA) for the analysis of the geochemical data in this study has informative results for exploration in the Jiama ore district (Zheng et al., in press), and has the potential to apply this method to regional prediction.

Compositional data are subject to the condition that the sum of the parent variables in any item is constant (closure effect), imposing a linear restraint which suppresses positive and increases negative covariance (Chayes, 1960), resulting in the issue of 'spurious correlation', as shown by Karl Pearson back in 1897 (Pawlowsky-Glahn, 2011; Pearson, 1897). Substantial developments and understanding in compositional data analysis have taken place since the Aitchison geometry was proposed (Aitchison, 1982; 1986; Egozcue et al., 2018; Pawlowsky-Glahn, 2011; Pawlowsky-Glahn et al., 2015; Van den Boogaart and Tolosana-Delgado, 2013). Compositional data analysis method is used to identify anomalies associated with stratigraphy, structures, magmatic rocks, distribution range of alteration and mineralization, which promotes better integration of geochemical anomalies and geological information.

This study establishes the regional metallogenic prediction model for the eastern part of the Tethys Himalayan metallogenic belt by summarizing the ore-control geological conditions and regional metallogenic regularity and integrating the geochemical anomalies obtained from CoDA.

\section{Geological background}

\subsection{Structure}

From north to south, the Qinghai-Tibet Plateau is divided into four terranes by Jinshajiang suture zone, Bangong-Nujiang suture zone and Indus-Yarlung Zangbo Suture Zone, which are Songpan-Ganzi terrane, Qiangtang terrane, Lhasa terrane and Himalayan terrane. The Himalayan terrane can be further divided into Tethys Himalaya, Higher Himalaya and lesser Himalaya by Southern Tibet Detachment System fault, Main Central Thrust and Main Boundary Thrust, and the south of Main Boundary Thrust is Indian plate (Fig. 1a; Pan et al., 2004; Yin et al., 2000; Yin, 2006). This study area is located in the eastern part of the Tethys Himalaya. According to the Lazi-Qiongduojiang suture zone, Lhunze fault and Lhozhag-Cuonadong fault, it can be divided into Langjiexue accretionary wedge, Nieru thrust structural belt, Lhunze-Comai-Nagarze fold belt and Lakang thrust structural belt from north to south (Fig. 1b). In addition to abundant faults and fold structures, the area also has a unique metamorphic core complex domes belt. More than ten bead-like metamorphic core complex domes have been found in the Tethys Himalayan belt (Beaumont et al., 2004; Zhang et al., 2012). In this study area, there are two outcrops, i.e. Yardoi and Ramba dome, both located near the late north-south tensional fault zone. The metamorphic core complex domes are closely related to the late structure (Fig. 1b; Aoya et al., 2005). The Tethys Himalayan dome is composed of Paleozoic and Precambrian greenschist to granulite facies metamorphic rocks and Eocene-Miocene leucogranite (Lee et al., 2004; 2006; Zhang et al., 2012).

\subsection{Stratigraphy}

The stratigraphy in the study area are mostly contacted and divided by faults. The Proterozoic strata are mainly exposed in the Higher Himalayan area south of Southern Tibet Detachment System and the metamorphic core complex dome, and the lithology is plagioclase gneiss, quartz schist and granulite. The Paleozoic strata are mainly phyllite, quartz schist, hornblende schist and 
marble, which are overlaid on the Proterozoic strata by fault contact. In the Permian, only a small

118 area of the Karela Formation is exposed in the south of the Ramba dome (Fig. 1b), and the

119 lithology is calcareous phyllite and crystalline limestone. Triassic strata belong to Nieru Formation,

120 mainly distributed in the west of the study area and between Lazi-Qiongduojiang suture and

121 Lhunze fault (Fig. 1b), and the lithology is mainly lithic quartz sandstone with local sericite slate.

122 The Jurassic strata in this area mainly consist of four Formations, which are the Ridang Formation,

123 the Lure Formation, the Zhela Formation and the Weimei Formaiton from lower to upper. The

124 main lithology is carbonaceous-calcareous slate and siltstone with tuff and thin limestone, which

125 are the main ore-bearing formation of Sb-polymetallic deposits in this area. Sangxiu Formation is

126 a special stratum in this area, which is just in the Jurassic/Cretaceous boundary in time, and its

127 lithology is dominated by bimodal volcanic rocks, which are basalt-rhyolite combination, with

128 conglomerate at the bottom. This stratum has important tectonic significance and is a sign of rift

129 sedimentation (Liu et al., 2013; Zhu et al., 2007). In the Cretaceous strata, the Jiabula Formation

130 and Zongzhuo Formation are exposed in the Lhunze-Comai-Nagarze fold belt (Fig. 1b), and the

131 lithology is feldspathic quartz sandstone with argillaceous rock and shale. In the Lakang thrust

132 structural belt, only the Lakang Formation is found (Fig. 1b), and the lithology is sericite slate,

133 siltstone with thin limestone, and there are also many layers of basalt in the stratum, which also

134 has certain tectonic significance (Yang et al., 2015). The Quaternary only occurs along the banks

135 of the Yarlung Zangbo River and lakes (Fig. 1b).

136 The age of Langjiexue group is Triassic, but this group is a set of tectonic slices, which is an

137 accretionary wedge formed during the subduction of the New Tethys ocean. The overall lithology

138 is lithic feldspathic quartz sandstone mixed with many of ophiolite, volcanic breccia, basalt and

139 other rock blocks (Li et al., 2016; Wang et al., 2016). There are a series of near East-West faults in

140 the group. Recently, some researchers have proposed that Nieru thrust nappe should also be

141 included in the accretionary wedge structure (Cai et al., 2016; Liu et al., 2020; Zhang et al., 2015).

142 2.3 Magmatic rocks

143 The magmatic rocks in the study area mainly include three parts. One is the ophiolite in the

144 Indus-Yarlung Zangbo Suture Zone, which is a set of peridotite, gabbro, diabase and basalt

145 assemblage. The zircon U-Pb age of the gabbro is $162.9 \pm 2.8 \mathrm{Ma}$ (Zhong et al., 2006), and the

146 ophiolite age measured by McDermid et al. (2002) in Zedong area is between 152-156 Ma.

147 Luobasha ophiolite belongs to the high titanium ophiolite suite of the oceanic tholeiite series,

148 which is the remnant of the paleo-oceanic crust (Wang et al., 1987), and belongs to the product of

149 the late Jurassic expansion of oceanic crust. The other is the Kerguelen-Bunbury-Comai Large

150 Igneous Province (Coffin et al., 2002; Zhu et al., 2009), which is characterized by bimodal

151 volcanic rocks of layered diabase-gabbro and veined rhyolite porphyry, and the rock ages are

152 concentrated at 130-145 Ma (Lin et al., 2014; Zhu et al., 2009). There is no obvious fractionation

153 of rare earth elements in basic volcanic rocks. Large ion lithophile elements such as $\mathrm{Rb}, \mathrm{Th}, \mathrm{Ba}, \mathrm{K}$,

$154 \mathrm{Sr}$ are depleted, and high field elements such as $\mathrm{Nb}, \mathrm{Ta}, \mathrm{Zr}$, Hf are weakly enriched. $\mathrm{The} \mathrm{Rb} / \mathrm{Sr}$

155 ratio is relatively low. The genesis of basic rocks is intraplate basalt series (Ma et al., 2018; Zhu et

156 al., 2007; 2008; 2009). This stage also includes volcanic strata in the Sangxiu Formation. The last

157 one is the leucogranite widely developed in southern Tibet, which is directly emplaced in the strata,

158 and also emplaced from the core of metamorphic core complex dome (Fig. 1b). The rock age is 

this area is mainly located in the Lhozhag, Cuonadong area and center of Yardoi and Ramba dome (Fig. 1b). The rock type is two-mica granite and muscovite granite, characterized by high potassium calc-alkaline and strong peraluminous. It is obviously enriched with $\mathrm{Rb}, \mathrm{Th}, \mathrm{U}, \mathrm{K}, \mathrm{Pb}$ and other large ion lithophile elements, and depleted of $\mathrm{Nb}, \mathrm{Ta}, \mathrm{P}$ and other high field strength elements, and significantly depleted of $\mathrm{Ba}$ and $\mathrm{Ti}$. The $\mathrm{Rb} / \mathrm{Sr}$ ratio is very high, greater than 5 (Huang et al., 2013; Lin et al., 2016), suggesting that it is a product of crustal remelting, closely related to Sb-polymetallic deposits and Sn mineralization in the area (Cao et al., 2020; Zheng et al., 2017).

\section{3. Mineralization types and features}

According to the current research and exploration results in the study area, the main types of deposits are composed of three types, including ophiolite chromite deposits, orogenic Au deposits and hydrothermal-vein Sb-polymetallic deposits, although there are still some controversies on the genesis of the latter two types. In the following, a typical deposit will be selected according to three types to describe its geological and geochemical characteristics and discuss their mineralization.

\subsection{Ophiolitic chromite deposit of Luobusha}

The Luobusha-Xiangkashan-Kangjinla chromite ore-concentrated area is located in the east section of the Indus-Yarlung Zangbo suture zone. The ore-bearing rock is about $41 \mathrm{~km}$ long from east to west and $250 \mathrm{~m}-3.7 \mathrm{~km}$ wide from south to north, which is distributed in the form of "S" (Fig. 1b). The accumulated amount of chromite ore resource is more than $6 \mathrm{Mt}, \mathrm{Cr}_{2} \mathrm{O}_{3} @ 48 \%$, PGE @ 0.5 ppm, and Cr / Fe ratio is more than 3.5 (Yang et al., 2018). The Luobusha deposit is located in the western part of the ore-concentrated area, and only the tertiary Luobusha group, which lies under the Indus-Yarlung Zangbo fault and dips to the south, composed of glutenite, is a set of Molasse Formation (Fig. 2a; Davis et al., 2004; Yin et al., 1999). The south side of the ore district is the accretionary wedge of Langjiexue group. The structure of the ore district is mainly north-south tensional-slip fault. The magmatic rocks in the area are bounded by the IndusYarlung Zangbo fault, with the Eocene granitic batholith of Gangdese in the north (Ji et al., 2009), the ophiolite in the south which belongs to the normal series of magnesian ultramafic rocks (M / F ratio is $8.8-11.6$ ), and the overall attitude of the rock body dips to the south. The lithofacies of ultramafic rocks are zonation. In the north zone, there is mainly ultramafic-mafic melange, almost no mineralization; in the middle zone, there is dunite, with a small amount of chromite; in the South zone, there is augite peridotite, which is the main ore-bearing zone (Fig. 2a). The main alteration in the deposit is serpentinization.

The Luobusha deposit is composed of dozens of orebodies, most of which are less than 100 $\mathrm{m}$ in strike, and a few of which are more than $200 \mathrm{~m}$. The geometry of the orebody is typical lenticular and podlike, dipping south (Fig. 2b). The ore is mainly of medium-dense disseminated structure, a few of which are massive, variegated and veined. The main metal mineral in the ore is picotite and a small amount of magnetite and goethite, and the main gangue mineral is olivine and serpentine, and a small amount of pyroxene and fuchsite. 
magmatic fractional crystallization mineralization, which occurs in the dunite facies. The orebody is consistent with the primary flow structure, and the ore is mostly disseminated structure, showing a gradual transition relationship with the wall rock. The other is the late pressure filtration mineralization, which mainly occurs in the dunite facies, as well as in the augite peridotite. The geometry of orebody is convex lens, and the ore is commonly banded and patchy structure, which has a vague relationship with the wall rock and is formed by the short-distance migration and enrichment after the residual intergranular melt is pressed out. The third is the liquation-injection mineralization, which occurs in the augite peridotite. The orebody shape is controlled by faults, and the boundary between the ore and the wall rock is clear, which may be the deep liquation of ore-bearing magma and inject fracture zone (Zhai et al., 2011).

\subsection{Orogenic Au deposit of Nianzha}

The Nianzha Au deposit occurs in the southern boundary fault in the Indus-Yarlung Zangbo suture zone which is a fault system (Fig. 1b). The deposit is a new gold deposit discovered in recent years. The ore resource of the deposit is $7 \mathrm{Mt}$, Au @ $3.2 \mathrm{~g} / \mathrm{t}$, and oxidized ore is developed on the surface. The sedimentary strata in the ore district are rare. The marble xenoliths in the quartz diorite may be the residual by the subduction of Seamount. Langjiexue accretionary wedge is mainly distributed in the south of the ore district. The faults of ore-control are NW-SE in strike, and the overall dip NE in the upper part, and SW in the lower part, which have the characteristics of ductile-brittle deformation. In addition, some later NE-SW tensional-slip faults are also found in the area (Fig. 3a). The fold structure of the ore district is relatively developed, and the anticline structure controls Au orebody (Fig. 3b). A large number of ophiolitic remains are found in the suture zone and Langjiexue accretionary wedge, and early Cretaceous diabase dikes are also widely distributed in this area (see section 2.3). The most widely distributed magmatic rock in the ore district is quartz diorite in the north, with the same age of early Cretaceous (Mo et al., 2005), which is a granitoid formed in the subduction stage of the New Tethys ocean. A few Eocene granite dikes intrude into quartz diorite (Fig. 3a). The main alteration in the deposit is silicification, followed by carbonatization.

Four main orebodies are delineated in the Nianzha Au deposit. The orebodies occur in vein like faults in the contact zone between quartz diorite and ophiolite and are controlled by faults and anticline (Fig. 3b). The occurrence of orebody is consistent with that of fracture zone, and the length in strike is generally more than $500 \mathrm{~m}$. The main gold-bearing minerals in the ore are limonite, pyrite and quartz, with a small amount of magnetite and carbonate minerals. The occurrence of gold in ore is mainly natural gold, which is wrapped in pyrite, limonite and quartz particles or filled in the cracks of these minerals. The particle size of gold is generally between $0.01-0.1 \mathrm{~mm}$. The $\mathrm{Au} / \mathrm{Ag}$ ratio in the ore is about 2 .

The Nianzha Au deposit occurs near the north of Langjiexue accretionary wedge formed by the subduction of the New Tethys ocean. The ore-bearing fault is of ductile-brittle structure, and silicification and carbonatization alteration are developed. The results of fluid inclusions in quartz vein related to gold mineralization show that the ore-forming fluid composition is $\mathrm{H}_{2} \mathrm{O}-\mathrm{NaCl}-$ organic gas fluid. The fluid homogenization temperature is between $203^{\circ} \mathrm{C}$ and $347^{\circ} \mathrm{C}$, and the

240 salinity is $0.35 \mathrm{wt} \%-17.17 \mathrm{wt} \% \mathrm{NaCl}$ equivalent. The $\delta^{18} \mathrm{O}_{\text {fluid }}$ values of single quartz mineral are $2410.15 \%-10.45 \%$, and corresponding $\delta \mathrm{D}_{\mathrm{V}-\mathrm{S} M O w}$ values are $-173 \% \%_{-}-96 \%$, and that, the $\delta{ }^{13} \mathrm{C}$ 
values are $-17.6 \%-4.7 \%$. Inclusion and isotopic datas indicate the ore-forming fluids were a mix of metamorphic and sedimentary orogenic fluids with the addition of some meteoric and mantle-derived fluids (Zhang et al., 2017). These characteristics are similar to those of typical orogenic Au deposits (Groves et al., 1998; Goldfarb et al., 2001), indicating that the genetic type of Nianzha Au deposit should be orogenic Au deposit.

It is worth noting that hundreds of quartz veinlet $\mathrm{Cu}-\mathrm{Au}$ mineralization can be discovered within about $1 \mathrm{~km}^{2}$ of the eastern surface of the ore district. The metallogenic potential of porphyry $\mathrm{Cu}-\mathrm{Au}$ deposit is discussed below (Fig. 3a).

\subsection{Hydrothermal-vein Sb-polymetallic deposit of Zhaxikang}

The Zhaxikang Sb-polymetallic deposit is located in Lhunze-Comai-Nagarze fold belt, which is the largest economic deposit found in the Tethys Himalayan belt. The proven metal resources of Zhaxikang deposit are 0.13 Mt Sb, 1.3 Mt Pb + Zn, 63.5 Moz Ag (Tibet Huayu Mining Co., Ltd., 2015). The strata in Zhaxikang ore district are relatively simple, which is the lower Jurassic Ridang Formation, with the lithology of carbonaceous slate and meta quartz sandstone (quartzite in part, Fig. 4a), and thin limestone in part. The structure of the ore district is a S-N trending tensional-slip fault, which controls the occurrence of the orebody. The type of magmatic rocks exposed in the ore district is relatively diversity. The oldest rock is Cambrian gneissic granite (Fig. 4a), which is the magmatic response of the Indian continent to Pan-African event (Xu et al., 2005). The most widely distributed magmatic rocks are bimodal diabase and rhyolite porphyry assemblages, with the diagenetic ages of $133 \mathrm{Ma} \pm$ and $135 \mathrm{Ma} \pm$ (Yang et al., 2014; Lin et al., 2014), which are part of the Kerguelen-Bunbury-Comai Large Igneous Province (Zhu et al., 2009). In addition, there are a few diorite dikes in the area. The alteration of the wall rock in the ore district is mainly silicification and $\mathrm{Fe}-\mathrm{Mn}$ carbonatization, which are related to $\mathrm{Sb}$ mineralization and $\mathrm{Pb}-\mathrm{Zn}$ mineralization respectively. Sericitization and chloritization can also be seen locally.

There are two orebodies in Zhaxikang deposit, No. V and VI (Fig. 4a), of which No. V orebody is the largest, accounting for $90 \%$ of the resources. No. V orebody occurs in the fault fracture zone in vein and lens shape, and the occurrence is basically the same as the fault. The length reaches $1200 \mathrm{~m}$ in strike, dips to the west, and the dip angle changes between $45^{\circ}-70^{\circ}$ (Fig. $4 \mathrm{~b})$. The typical ore structures are breccial, banded and veined. The main metallic minerals in the ore are stibnite, galena, sphalerite, a small amount of freibergite and boulangerite, and the non-metallic minerals are quartz and Fe-Mn carbonate minerals. Mineralization in the deposit has obvious zonation, from shallow to deep, $\mathrm{Sb}(\mathrm{Ag}) \rightarrow \mathrm{Pb}+\mathrm{Ag}(\mathrm{Zn}+\mathrm{Sb}) \rightarrow \mathrm{Zn}+\mathrm{Pb}(\mathrm{Ag}+\mathrm{Cu})$ (Zheng et al., 2017)

The genesis of Zhaxikang deposit is the most controversial in the Tethys Himalayan belt. The main viewpoints are divided into two types. The researchers who advocate the exhalation sedimentation mineralization believe that there are two mineralization processes in Zhaxikang. The early exhalation sedimentation forms $\mathrm{Fe}-\mathrm{Mn}$ carbonate-sulfide mineral assembles and $\mathrm{Pb}-$ $\mathrm{Zn}-\mathrm{Ag}-\mathrm{Mn}-\mathrm{Fe}$ mineralization, and the later is hot spring mineralization, forming quartz-calcitesulfide mineral assembles and Sb-Hg mineralization (Zhang et al.,, 2010; Zheng et al., 2012; Zhu et al., 2012). The researchers who advocate hydrothermal mineralization believe that the orebody is strictly controlled by faults, with obvious breccial, miarolitic and veined ore structure, and 
diabase can be one of the breccias (Fig. 4b, indicating that the mineralization age must be later than $133 \mathrm{Ma}$ ). Microscopic identification also found a wide range of metasomatic and residual textures related to hydrothermal metasomatism (Wang et al., 2012). The mineralization is characterized by low temperature and high temperature element zonation from shallow to deep, and the Sn content of more than $600 \mathrm{ppm}$ has been measured in the single mineral of sphalerite in the deep (Zhang et al., 2016). It is proposed that the Zhaxikang deposit is a hydrothermal-vein type polymetallic deposit related to the genesis of the leucogranite in the south of the Cuonadong (Lin et al., 2016), and it is considered that the Sn orebody may be found in the deep or peripheral (Zheng et al., 2017). Recent geological exploration results also confirm the prediction (Cao et al., 2020; Li et al., 2017).

\section{Multi-element geochemical signatures}

\subsection{Geochemical data}

The geochemical dataset used in this study was collected via stream sediment sampling as part of the "Regional Geochemistry National Reconnaissance (RGNR) Project" which was initiated in 1979 and has now covered more than 7 million $\mathrm{km} 2$ of China. The sample density is 1 per $7 \mathrm{~km}^{2}$, and a total of 9,165 samples are included in this research. Samples have undergone multi-element analysis of 39 elements (including $\mathrm{Bi}, \mathrm{Cu}, \mathrm{P}, \mathrm{La}, \mathrm{Li}, \mathrm{Ag}, \mathrm{Sn}, \mathrm{Au}, \mathrm{Mo}, \mathrm{Th}, \mathrm{U}, \mathrm{W}, \mathrm{Sb}$, $\mathrm{Hg}, \mathrm{Mn}, \mathrm{Cr}, \mathrm{Sr}, \mathrm{Nb}, \mathrm{Pb}, \mathrm{Ni}$, Ti, Y, Cd, Co, Ba, Be, V, Zn, B, As, Zr, F, Fe2O3, K2O, CaO, MgO, $\mathrm{Na} 2 \mathrm{O}, \mathrm{Al} 2 \mathrm{O} 3, \mathrm{SiO} 2$ ) (Xie et al., 1997). The 39 elements were analysed by various methods including ICP-MS, XRF and ICP-AES. The specific test methods, detection limits, quality control and other information corresponding to each element have been published by Wang et al., 2007, Xie et al., 2008 and Xie et al., 1997 and are not repeated here.

\subsection{Methodology}

This study uses a knowledge-driven Compositional Data Analysis (CoDA) framework to investigate the geochemical data which includes the use of isometric log-ratio transformations (ilr), and sequential binary partition (SBP). CoDaPack software (Comas-Cufí et al., 2011), developed by the Research Group in Statistics and Compositional Data Analysis at University of Girona, is used in this analysis.

\subsubsection{Logratio transformation}

Within compositional theory (Aitchison, 1982; 1986), the additive log-ratio (alr) (Aitchison, 1986), the centered log-ratio (clr) (Aitchison, 1986), and the isometric log-ratio (ilr) (Egozcue et al., 2003; Filzmoser et al., 2012) transformations have been proposed to deal with the data 'closure problem' which can be used to transform raw data (e.g. geochemical data) from the 'simplex' to 'Euclidean space'.

The D-part compositional data $x=\left(x_{1}, x_{2}, \ldots, x_{D}\right)$, the alr [Eq. (1)], clr [Eq. (2)] and ilr [Eq. (3)] transformation of each part $x_{i}(i=1,2, \ldots, D)$ can be expressed as follow:

$y_{i}=\log \frac{x_{i}}{x_{D}} \quad(i=1,2, \ldots, D-1)$ 
$y_{i}=\sqrt{\frac{D-i}{D-i+1}} \log \frac{x_{i}}{\sqrt[D-i]{\prod_{j=i+1}^{D} x_{j}}}(i=1,2, \ldots, D-1)$

Each of these three transformations has advantages and disadvantages. The alr is relatively straightforward to apply but the choice of denominator can be arbitrary. The clr transformation is straightforward but results may be affected by data collinearity as the sum of the clr-transformed data is zero. The ilr transformation is an orthogonal transformation and forms one-to-one relations between the Aitchison geometry on the simplex and the standard Euclidean geometry, with excellent geometrical properties, but results can be difficult to interpret (Filzmoser et al., 2012; Wang et al., 2014).

\subsubsection{Sequential binary partition (SBP)}

The Sequential binary partition (SBP) approach is proposed as a tool for compositional data analysis for dimension reduction through orthonormal basis transformation (Egozcue and Pawlowsky-Glahn, 2005).

The key of the SBP approach is the design of ilr-coordinates or compositional balances. Balances are particular ilr-coordinates with orthonormal bases which can be interpreted in the D-1 dimension real space as ratios of elemental associations (Egozcue et al., 2003; Petrik et al., 2018). To deal with D-parts compositional vectors $\left[x_{1}, x_{2}, \ldots, x_{D}\right]$ in the simplex space, the first-order binary partition consists of making two groups of parts; the second-order partition is obtained by subdividing one of the first-order groups into two groups; the procedure is iterated until all groups contain only a single part. The number of binary divisions of a group to attain the end of the process is D-1, and this D-parts dataset has already been separated into non-overlapping D-1 groups or balances (subcompositions) of parts (Egozcue and Pawlowsky-Glahn, 2005; Liu et al., 2019).

The formula of compositional balances calculation is shown below [Eq. (4); Egozcue and Pawlowsky-Glahn, 2005; Petrik et al., 2018]:

$z_{i}=\sqrt{\frac{r s}{r+s}} \ln \frac{\left(\Pi_{+} x_{j}\right)^{1 / r}}{\left(\Pi_{-} x_{k}\right)^{1 / s}} \quad$ for $i=1,2, \ldots \ldots, D-1 ; j=1,2, \ldots, r ; k=1,2, \ldots, s$

where $\prod_{+} x_{j}$ is the product involves $r$ positive parts coded with + in the $i$-th order partition, while $\prod_{-} x_{k}$ is the product involves $s$ negative parts coded with - in the i-th order partition, respectively.

\subsection{Knowledge-driven ilr Balances design and mapping}

In terms of geochemical compositional data, each compositional balance can be seen as a meaningful log-contrast with different data- or knowledge-driven elements associations (McKinley et al., 2016), where data-driven methods include hierarchical clustering, k-means, and so on, while knowledge-driven elements associations depend on the deep understanding in the geology and geochemistry background of the certain research area. Therefore, the compositional balance is a reasonable way to extract geochemical associations and can provide an interpretation 
for the underlying geological, environmental and metallogenic framework.

According to the geological background, mineralization types and geochemical survey, some knowledge can be found. The element association $\mathrm{K}_{2} \mathrm{O}-\mathrm{Na}_{2} \mathrm{O}$ can be seen as sandstone signature; the association $\mathrm{Co}-\mathrm{V}-\mathrm{Mn}-\mathrm{CaO}-\mathrm{Ti}$ usually has a high value in black rock series; accretionary structure zone take a high value of $\mathrm{Al}_{2} \mathrm{O}_{3}$; leucogranite is a main type of acid rock, and causes $\mathrm{Pb}$ $\mathrm{K}_{2} \mathrm{O}-\mathrm{Th}-\mathrm{U}$ enrichment; mafic-ultramafic rocks include peridotite, diabase has a high value of $\mathrm{Cr}-$ $\mathrm{Ni}-\mathrm{Ti}-\mathrm{MgO}$; geochemical association $\mathrm{Cr}-\mathrm{Ni}$ can indicate Chromite mineralization; $\mathrm{Au}-\mathrm{Cu}-\mathrm{Mo}$ can indicate $\mathrm{Au}$ and $\mathrm{Cu}-\mathrm{Au}$ mineralization; $\mathrm{Hg}-\mathrm{Sb}-\mathrm{Pb}-\mathrm{Ag}-\mathrm{Zn}-\mathrm{Cd}-\mathrm{As}$ is a useful geochemical signature of Sb-polymetallic mineralization and $\mathrm{Sn}-\mathrm{Be}-\mathrm{Li}-\mathrm{B}-\mathrm{F}-\mathrm{Nb}$ can reflect the location of $\mathrm{Sn}(\mathrm{Be})$ mineralization. Meanwhile, taking the element depletion association as a "contrast" for each enrichment association above to design 9 ilr balances showed in Table.1. Corresponding ilr balance maps (Fig.5) generated by Equation (4) are log-contrast between two groups of parts within the Table. So every ilr balance may have a valid meaning for interpretation.

\section{Discussion}

\subsection{Geological conditions for ore-control}

For the chromite deposits in this area, the ophiolitic remains in the plate suture zone are important exploration directions, while the dunite facies and augite peridotite facies in the ophiolite are important targets for chromite deposit, and the enrichment degree of chromite is often strongly related to the alteration degree of serpentinization. The existence of liquationinjection mineralization in Luobusha indicates that the formation of chromite is not completely controlled by the differentiation-crystallization of ultramafic rocks, and faults are more important for the formation of chromite under the condition of obduction and emplacement mechanism similar to that of Indus-Yarlung Zangbo ophiolite.

The accretionary wedge / accretionary terrane of subduction suture zone is undoubtedly an important tectonic condition for the formation of orogenic Au deposits (Groves et al., 1998; Goldfarb et al., 2001). Therefore, Langjiexue Group including part of Nieru Formation are the favorable place for the formation of orogenic Au deposits such as Nianzha, Bangbu and Chalapu. Where affected by the accretionary wedge structure, it can also form orogenic Au deposits, such as those in Nagarze area, but the scale of the deposits is small. It is also important for the formation of orogenic Au deposits that ore-control faults have the dual ductile-brittle properties. The data of fluid inclusions and isotopes of deposits such as Nianzha and Bangbu indicate that the fluid properties are dominated by metamorphic fluid as well as the addition of mantle-derived fluid (Zhang et al., 2017). This extensive magmatic activity is also favorable for the formation of deposits. In the accretionary wedge structure of the study area, except orogenic Au deposits, it is also very important to estimate the metallogenic potential of porphyry $\mathrm{Cu}-\mathrm{Au}(\mathrm{Mo})$ deposits, and the key issue is, for example, whether the Cretaceous quartz diorite in Nianzha area is the continental arc granite or the intra-oceanic arc granite. If it is the intra-oceanic arc granite and the quartz diorite is spliced on the Lhasa terrane as a accretionary terrane, it is very likely to discovery the "Xiongcun-type" porphyry $\mathrm{Cu}-\mathrm{Au}$ deposit (Tang et al., 2015). Fortunately, it has been found 
Zhongba and Nedong area of the Indus-Yarlung Zangbo suture zone (Aitchison et al., 2000; Dai et 401 al., 2011)。

402 The Sb-polymetallic deposits in this area are mainly distributed in the Lhunze-Comai fold

403 belt, and there are also a few mineral occurrences in the Lakang thrust belt in the south. The strata 404 related to Sb-polymetallic deposits are mainly the black rock series (carbonaceous slate), which 405 may provide some metal sources for the formation of the deposits ( $\mathrm{Li}$ et al., 2014). Faults control 406 the deposit, and ore-bearing faults are generally characterized by tensional-slip. Regional 407 leucogranite provides an important material source for mineralization (Duan et al., 2016). 408 According to the $\mathrm{Sn}(\mathrm{Be})$ mineralization which has been found in the contact zone of the 409 leucogranite in the Cuonadong (Cao et al., 2020; Li et al., 2017), the periphery of Zhaxikang ore 410 district, and in Nepal (Mitchell et al., 1976), these Sb-polymetallic veins may only be the 411 medium-low temperature mineralized body around the real Sn deposit, which is very similar to 412 Xianghualing Sn deposit in Hunan Province and Dachang Sn deposit in Guangxi Province, China 413 (Chen et al., 1988; Du, 1983).

\section{$414 \quad 5.2$ Tectonic evolution-magmatism and regional metallogeny}

415 The earliest tectonic and magmatic activity found in the Tethys Himalaya is Cambrian, which 416 is a response to Pan-African orogenic events. However, whether there is a metallogenic response 417 similar to the Central African Copperbelt has not been found. At present, the earliest 418 mineralization recorded in this area is chromite deposit in the Indus-Yarlung Zangbo suture zone, 419 which was formed in the late Jurassic with the background of the initial break-up of the New 420 Tethys ocean basin (McDermid et al., 2002; Zhong et al., 2006). The mechanism of the reverse 421 location of chromite-bearing ophiolite and the molasse formation of the underlying Luobusha 422 Group on the Gangdese batholith is the obduction of the Indian terrane towards the Lhasa terrane during the late collision-detachment stage (Fig. 6; Wang et al., 2000; Wang et al., 2015).

In the early Cretaceous, under the action of Kerguelen mantle plume, the Indian terrane disintegrated from the East Gondwana continent, and the area began to be in rift environment, with the development of large-scale bimodal volcanic rocks and the formation of KerguelenBunbury-Comai Large Igneous Province (Coffin et al., 2002; Zhu et al., 2009), whether there are deposits related to intra-continental rifting environment or hot spot activity in this stage remains to be studied, such as Sullivan-type $\mathrm{Pb}-\mathrm{Zn}$ deposit in British Columbia, $\mathrm{Sn}-\mathrm{Nb}-\mathrm{U}$ deposit related to peralkaline granite in Jos Plateau of Nigeria, $\mathrm{Cr}-\mathrm{Ni}-\mathrm{Pt}-\mathrm{Cu}$ deposit in layered mafic-ultramafic rocks in South Africa-Zimbabwe, etc. (Mitchell et al., 1976; 1981). At this time, however, the occurrence of small-scale intra-oceanic subduction in the New Tethys ocean and the formation of intra-oceanic arc rocks have been confirmed in some areas (Aitchison et al., 2000; Dai et al., 2011), which points out an important direction for the exploration of "Xiongcun-type" island arc porphyry $\mathrm{Cu}-\mathrm{Au}$ deposit (Tang et al., 2015), such as the exploration targets in Nianzha ore district and some island arc quartz diorite in Nedong area.

Since Paleogene, with the occurrence of continent-continent collision in India-Lhasa terrane, the Langjiexue accretionary wedge in the Tethys Himalayan region has undergone strong thrust and compression, forming an orogenic Au deposit (Fig. 6). Subsequently, the occurrence of

440 Southern Tibet Detachment System led to large-scale crustal plastic rheology and remelting in the 441 Tethys Himalayan belt, forming a metamorphic core complex dome belt and a large-scale 

number of hydrothermal-vein type Sb-polymetallic deposits in the Lhunze-Comai-Nagarze fold belt (Fig. 6). The Sn mineralization related to leucogranite may be an important exprolation direction in the region and the Higher Himalayan belt in the future (Mitchell et al., 1981; Zheng et al., 2017).

\subsection{Significance of geochemical anomalies}

Identification of stratigraphy/lithology: Sedimentary rocks play an important role in some mineralization of the area, especially the black rock series play a certain role in controlling the formation of Sb-polymetallic deposits. According to lithology and sedimentary environment, sedimentary rocks in the study area are mainly divided into two categories: one is mediumcoarse-grained lithic quartz sandstone formed in Triassic regressive / shallow sea environment, including Langjiexue Group and Nieru Formation; the other is black rock series formed in Jurassic-Cretaceous transgressive environment, mainly composed of carbonaceous slate and sericite slate (Gradstein et al., 2005). Balance 1 (B1) obtained by CoDA element combination is $\mathrm{K}_{2} \mathrm{O}-\mathrm{Na}_{2} \mathrm{O}$ vs $\mathrm{As}-\mathrm{Cd}-\mathrm{Zn}-\mathrm{Pb}-\mathrm{Ag}-\mathrm{Au}-\mathrm{Hg}-\mathrm{Sb}-\mathrm{Fe}_{2} \mathrm{O}_{3}-\mathrm{Mo}-\mathrm{W}-\mathrm{Bi}-\mathrm{Sn}-\mathrm{Be}-\mathrm{Cu}-\mathrm{Cr}-\mathrm{Ni}-\mathrm{Ti}-\mathrm{MgO}-$ $\mathrm{Li}-\mathrm{B}-\mathrm{F}-\mathrm{Th}-\mathrm{U}-\mathrm{Ba}-\mathrm{Nb}-\mathrm{Sr}-\mathrm{P}-\mathrm{Al}_{2} \mathrm{O}_{3}-\mathrm{CaO}-\mathrm{Co}-\mathrm{V}-\mathrm{Mn}-\mathrm{La}-\mathrm{Zr}-\mathrm{Y}-\mathrm{SiO}_{2}$ (Table 1). The high value anomaly represents the alkalinity in the rocks, and clearly identifies the distribution area of Triassic sandstone (Fig. 5a), indicating that the source area of Triassic sandstone may be alkali rich non-orogenic granites, which is consistent with the stable continental environment of East Gondwana at this time (Frisch et al., 2011). In contrast, the high value anomaly of B2 (Co-V$\mathrm{Mn}-\mathrm{CaO}-\mathrm{Ti}$ vs $\mathrm{U}-\mathrm{Ba}$, Table 1) assemblage clearly reflects the distribution area of black rock series in the study area (Fig. 5b). The black rock series reflects the characteristics of rich organic matter in sediments in anoxic environment. It is a set of rock assemblages with reduced properties, which has always been very important for the formation of non-ferrous metals (Meyers et al., 1992).

Identification of accretionary wedge: There is always a dispute on the division of the southern boundary of the Langjiexue accretionary wedge in the study area. The key to the dispute is whether to take Lazi-Qiongduojiang suture zone as the boundary or Lhunze fault as the boundary, that is, the ownership of the Nieru thrust structural belt (Cai et al., 2016; Li et al., 2010; Tibetan Bureau of Geology and Mineral Resources, 1993; Wang et al., 2016; Webb et al., 2013). The results of element combination of $\mathrm{B} 3\left(\mathrm{Al}_{2} \mathrm{O}_{3}\right.$ vs $\left.\mathrm{CaO}\right)$ show that (Table 1), the high value area obviously reflects the distribution range of accretionary wedge structure, including Nieru thrust structural belt (Fig. 5c). It indicates that Nieru thrust structural belt should belong to Langjiexue accretionary wedge, which is consistent with recent research results (Cai et al., 2016; Liu et al., 2020; Zhang et al., 2015). B3 does not reflect the distribution area of large area Nieru Formation in the west of Lhozhag. It also shows that the content of B3 reaction is obviously different from $\mathrm{B} 1$, mainly reflecting the range of accretionary wedge structural belt (Fig. 5c). The extensive greenschist facies alteration of accretionary wedge indicates that in the process of collisional orogeny, a large number of metasomatism dominated by metamorphic fluid is caused by compression, which forms aluminum rich silicate alteration (Wang et al., 2000). This is the basic reason that $\mathrm{B} 3$ can recognize the accretionary wedge structural belt. 
$\mathrm{Ba}-\mathrm{Nb}$, Table 1) clearly reflects the distribution of leucogranite in the area, including Lhozhag leucogranite with the largest distribution area, Cuonadong, and leucogranite in Yardoi and Ramba dome (Fig. 5d). This set of element assemblage is consistent with the geochemical characteristics and petrogenetic types of leucogranite in the study area, and belongs to the granite formed by crustal remelting (Huang et al., 2013; Lin et al., 2016; Liu et al., 2019; Zeng et al., 2011).

Identification of mafic to ultramafic rocks: Element combination of $\mathrm{B} 5(\mathrm{Cr}-\mathrm{Ni}-\mathrm{Ti}-\mathrm{MgO}$ vs $\mathrm{As}-\mathrm{Cd}-\mathrm{Zn}-\mathrm{Pb}-\mathrm{Ag}-\mathrm{Au}-\mathrm{Hg}-\mathrm{Sb}-\mathrm{Fe}_{2} \mathrm{O}_{3}-\mathrm{Mo}-\mathrm{W}-\mathrm{Bi}-\mathrm{Sn}-\mathrm{Be}-\mathrm{Cu}-\mathrm{Li}-\mathrm{B}-\mathrm{F}-\mathrm{Th}-\mathrm{U}-\mathrm{K}_{2} \mathrm{O}-\mathrm{Ba}-\mathrm{Nb}-\mathrm{Sr}-$ $\mathrm{P}-\mathrm{Al}_{2} \mathrm{O}_{3}-\mathrm{CaO}-\mathrm{Co}-\mathrm{V}-\mathrm{Mn}-\mathrm{La}-\mathrm{Zr}-\mathrm{Y}-\mathrm{Na}_{2} \mathrm{O}-\mathrm{SiO}_{2}$, Table 1) different from $\mathrm{B} 4$, it reflects the distribution range of mafic-ultramafic rocks, mainly including ophiolite in the Indus-Yarlung Zangbo suture zone, melange block in Langjiexue accretionary wedge, and the distribution area of volcanic rocks in Sangxiu Formation and some of the Lakang Formation (Fig. 5e).

Identification of chromite mineralization: On the basis of $\mathrm{B} 5$, this study chooses $\mathrm{B} 6(\mathrm{Cr}-\mathrm{Ni}$ vs $\mathrm{Ti}-\mathrm{MgO}$ ) element combination for further anomaly interpretation of mafic-ultramafic rocks (Table 1). It is found that the high value anomaly area well delineates the distribution area of chromite mineralization (Fig. 5f), which is an important set of element combination for identifying chromite mineralization in this area. It is worth noting that in addition to the LuobushaXiangkashan-Kangjinla ore concentration area and the anomaly are very corresponding to the past, the ophiolitic belt with a length of more than $50 \mathrm{~km}$ in Nedong area also shows very good chromite anomaly information (Fig. 5f), and at present dozens of mineral occurrences have been found in this area, which is worth further exploration.

Identification of $\mathrm{Au}(\mathrm{Cu})$ mineralization: The $\mathrm{B} 7$ element combination $(\mathrm{Au}-\mathrm{Cu}-\mathrm{Mo} v s \mathrm{Sb}-$ $\mathrm{Pb}-\mathrm{Zn}-\mathrm{Ag}$, Table 1) obtained in this study is a group of important geochemical anomalies based on the understanding of regional mineralization. On the one hand, the anomalies of this group have well delineated the scope of gold mineralization, but different from other research methods (Sun et al., 2016), the high values of $\mathrm{Au}-\mathrm{Cu}-\mathrm{Mo}$ have several abnormal areas near the suture zone, such as Nianzha Au ore district, Sangri and Gyaca area (Fig. 5g). These areas have revealed copper and gold mineralization in Early Cretaceous quartz diorite (Fig. 3a; Aitchison et al., 2000; Dai et al., 2011), which is possible that the intra-oceanic island arc was spliced onto the Lhasa terrane as a accretionary terrane. Therefore, there is a great potential to find "Xiongcun-type" island arc porphyry $\mathrm{Cu}-\mathrm{Au}$ deposits in these anomaly areas. In terms of the exploration direction of individual Au deposits, the high value anomaly delineated by Qonggyai-Qusum area is likely to be similar to the discovered Bangbu-Xigong-Muda gold concentration area (Fig. 5g), and multiple mineral occurrences are also found on the surface, which is worthy of further work.

Identification of Sb-polymetallic mineralization: Element combination of $\mathrm{B} 8(\mathrm{Hg}-\mathrm{Sb}-\mathrm{Pb}-$ $\mathrm{Ag}-\mathrm{Zn}-\mathrm{Cd}-\mathrm{As}$ vs $\mathrm{Au}-\mathrm{Fe}_{2} \mathrm{O}_{3}-\mathrm{Mo}-\mathrm{W}-\mathrm{Bi}-\mathrm{Sn}-\mathrm{Be}-\mathrm{Cu}-\mathrm{Cr}-\mathrm{Ni}-\mathrm{Ti}-\mathrm{MgO}-\mathrm{Li}-\mathrm{B}-\mathrm{F}-\mathrm{Th}-\mathrm{U}-\mathrm{K}_{2} \mathrm{O}-\mathrm{Ba}-$ $\mathrm{Nb}-\mathrm{Sr}-\mathrm{P}-\mathrm{Al}_{2} \mathrm{O}_{3}-\mathrm{CaO}-\mathrm{Co}-\mathrm{V}-\mathrm{Mn}-\mathrm{La}-\mathrm{Zr}-\mathrm{Y}-\mathrm{Na}_{2} \mathrm{O}-\mathrm{SiO}_{2}$, Table 1) reflects the distribution range of Sb-polymetallic mineralization in the study area, and the anomaly areas with high value over 0.72 corresponds very well to the two main ore concentration areas Zhaxikang-Keyue-Yufeng and Yongri-Rangla-Cheqiongzhuobu (Fig. 5h), indicating the applicability of the anomaly combination. However, it is difficult to discover this type of deposit with a certain scale in other places according to the anomaly distribution map.

Identification of $\mathrm{Sn}(\mathrm{Be})$ mineralization: As mentioned above, Sn mineralization has 
important exploration significance in the Tethys Himalayan belt and even the whole Himalayan 527 fold orogenic belt (Cao et al., 2020; Li et al., 2017; Mitchell et al., 1981; Zheng et al., 2017). The B9 ( $\mathrm{Sn}-\mathrm{Be}-\mathrm{Li}-\mathrm{B}-\mathrm{F}-\mathrm{Nb}$ vs $\mathrm{As}-\mathrm{Cd}-\mathrm{Zn}-\mathrm{Pb}-\mathrm{Ag}-\mathrm{Au}-\mathrm{Hg}-\mathrm{Sb}-\mathrm{Fe}_{2} \mathrm{O}_{3}-\mathrm{Mo}-\mathrm{W}-\mathrm{Bi}-\mathrm{Cu}-\mathrm{Cr}-\mathrm{Ni}-\mathrm{Ti}-$ $\mathrm{MgO}-\mathrm{Th}-\mathrm{U}-\mathrm{K}_{2} \mathrm{O}-\mathrm{Ba}-\mathrm{Sr}-\mathrm{P}-\mathrm{Al}_{2} \mathrm{O}_{3}-\mathrm{CaO}-\mathrm{Co}-\mathrm{V}-\mathrm{Mn}-\mathrm{La}-\mathrm{Zr}-\mathrm{Y}-\mathrm{Na}_{2} \mathrm{O}-\mathrm{SiO}_{2}$ ) obtained in this study, high value anomalies delineate four major anomaly areas that are closely related to leucogranite (Fig. 5i), which is also consistent with the conclusion of regional metallogenic regularity summarized in the previous paper. Sn mineralization (skarn type, quartz vein type, greisen type, etc.) related to leucogranite may be an important exploration direction in this area and Himalayan orogenic belt in the future (Mitchell et al., 1981; Zheng et al., 2017).

\subsection{Metallogenic prediction model}

Based on the analysis of three main deposit types (ophiolite chromite deposit, orogenic Au deposit and hydrothermal-vein Sb-polymetallic deposit) and two types of predicted deposits (island arc type porphyry $\mathrm{Cu}-\mathrm{Au}(\mathrm{Mo})$ deposit and $\mathrm{Sn}(\mathrm{Be}-\mathrm{U})$ deposit related to leucogranite, the relationship between tectonic evolution-magmatism and metallogeny in this area is summarized, and the time and space of regional mineralization is established. The regional metallogenic prediction model is established by combining geological information with geochemical anomalies based on CoDA method (Fig. 6). On this basis, this study considers that the deposit types and areas worthy of further exploration are: (1) the ophiolitic belt with a length of $50 \mathrm{~km}$ in Nedong area is favorable for exploration of chromite deposits; (2) the $\mathrm{Au}-\mathrm{Cu}-\mathrm{Mo}$ high value anomaly area in Qonggyai-Qusum area has the prospect of exploration for orogenic Au deposits; (3) the $\mathrm{Au}-$ $\mathrm{Cu}-\mathrm{Mo}$ high value anomalies in Nianzha, Sangri and Gyaca areas are the key exploration target areas of "Xiongcun-type" island arc porphyry $\mathrm{Cu}-\mathrm{Au}$ deposit; (4) the deep part of Sb-polymetallic deposit and the inner-outer contact zone of Lhozhag and Cuonadong leucogranite may be the important breakthrough of $\mathrm{Sn}(\mathrm{Be}-\mathrm{U})$ deposit.

\section{Conclusions}

This study suggests that there are three main types of deposits in the Tethys Himalayan belt, including ophiolite chromite deposit, orogenic Au deposit and hydrothermal-vein Sb-polymetallic deposit. The ophiolite chromite deposit was formed in the early stage of the expansion of the New Tethys ocean basin. The main host rock is augite peridotite. Serpentinization is strongly related to mineralization and enrichment. The orogenic Au deposits are formed in the accretionary wedge structural belt. In the environment of intense compression during collision stage, the contact zone of sandstone-slate / ophiolite or ophiolite / quartz diorite is the main ore-bearing structure. The anticline controls the location of the Au orebody. The silicification and carbonatization are closely related to the gold mineralization. Hydrothermal-vein Sb-polymetallic deposits are mainly formed in Lhunze-Comai-Nagarze fold belt. The occurrence of orebodies is controlled by extensionalslip faults. The black rock series also controls the deposits. Silicification and $\mathrm{Fe}-\mathrm{Mn}$ carbonatization are related to $\mathrm{Sb}$ mineralization and $\mathrm{Pb}-\mathrm{Zn}$ mineralization, respectively.

The geochemical anomalies revealed through a combination of geological knowledge and compositional data analysis of geochemical data have enabled the interpretation of the distribution range and regularity of sedimentary strata, accretionary wedge structure, leucogranite, maficultramafic rocks, chromite mineralization, Au mineralization and Sb-polymetallic mineralization 
in the study area.

Based on the combination of geological information and analysis of geochemistry, it is considered that there may be two new types of deposits in the study area, island arc type porphyry $\mathrm{Cu}-\mathrm{Au}(\mathrm{Mo})$ mineralization and $\mathrm{Sn}(\mathrm{Be}-\mathrm{U})$ mineralization related to leucogranite

\section{Acknowledgments}

This work was supported by the National Key R\&D Program of China (2017YFC0601505, 2018YFC0604101), National Natural Science Foundation of China (41602334, 41672325) and Opening Fund of Geomathematics Key Laboratory of Sichuan Province (scsxdz2018zd03). We sincerely appreciate Huayu Mining Company and Tibet Mining Company for their support.

\section{References}

Aitchison, J., 1982. The statistical analysis of compositional data. J. R. Stat. Soc. Ser. B (Stat. Methodol.) 44 (2), $139-177$.

Aitchison, J., 1986. The statistical analysis of compositional data. Chapman and Hall Ltd., London, pp. 1-416.

Aitchison, J.C., Ba, D.Z., Davis, A.M., Liu, J.B., Luo, H., Malpas, J.G., McDermid, I.R.C., Wu, H.Y., Ziabrev, S.V., Zhou, M.F., 2000. Remnants of a Cretaceous intra-oceanic subduction system within the YarlungZangbo suture (southern Tibet). Earth Planet. Sci. Lett. 183(1-2), 231-244.

Aoya, M., Wallis, S.R., Terada, K., Lee, J., Kawakami, T., Wang, Y., Heizler, M., 2005. North-south extension in the Tibetan crust triggered by granite emplacement. Geology 33, 853-856.

Beaumont, C., Jamieson, R.A., Nguyen, M,H., Medvedev, S., 2004. Crustal channel flows: 1.Numerical models with applications to the tectonics of the Himalayan-Tibetan orogen. J. Geophys. Res. 109, 1-29.

Cai, F.L., Ding, L., Laskowski, A.K., Kapp, P., Wang, H.Q., Xu, Q., Zhang, L.Y., 2016. Late Triassic paleogeographic reconstruction along the Neo-Tethyan Ocean margins, southern Tibet. Earth Planet. Sci. Lett. 435, 105-114.

Cao, H.W., Li, G.M., Zhang, Z., Zhang, L.K., Dong, S.L., Xia, X.B., Liang, W., Fu, J.G., Huang, Y., Xiang, A.P., Qing, C.S., Dai, Z.W., Pei, Q.M., Zhang, Y.H., 2020. Miocene Sn polymetallic mineralization in the Tethyan Himalaya, southeastern Tibet: A case study of the Cuonadong deposit. Ore Geol. Rev. 119, 103403 Crossref.

Chen, Y.C., Huang, M.Z., Xu, Y., Ai, Y.D., Li, X.M., Tang, S.H., Meng, L.K., 1988. Geological and metallogenic features and model of the Dachang cassiterite-sulphide polymetallic ore belt, Guangxi, China. In: Hutchison, C.S. (Eds.), Geology of tin deposits in Asia and the Pacific. Springer, Berlin, pp. 358-372.

Cheng, L.J., Du, G.W., 2001. Progress and major achievements in geochemical exploration of the Tibetan plateau. Geol. China 28(1), 46-48 (in Chinese).

Coffin, M.F., Pringle, M.S., Dungan, R.A., Gladczenko, T.P., Storey, M., Muller, R.D., Gahagan, L.A., 2002. Kerguelen hotspot magma output since 130 Ma. J. Petrol. 43, 1121-1139. In: Egozcue, J.J., Tolosana-Delgado, R., Ortego, M.I. (Eds.), CoDaWork'11: 4th International Workshop on Compositional Data Analysis. Sant Feliu de Guíxols. 
Davis, A.M., Aitchison, J.C., Badengzhu, Hui, L., 2004. Conglomerates of the Yarlung-Tsangpo suture zone, southern Tibet. In: Malpas, J., Fletcher, C.J.N., Ali, J.R., Aitchison, J.C. (Eds.), Aspects of the Tectonic Evolution of China. Geol. Soc. London, Spec. Publ. 226, pp. 235-246.

Dai, J.G., Wang, C.S., Hebert, R., Santosh, M., Li, Y.L., Xu, J.Y., 2011. Petrology and geochemistry of peridotites in the Zhongba ophiolite, Yarlung Zangbo Suture Zone: Implications for the Early Cretaceous intra-oceanic subduction zone within the Neo-Tethys. Chem. Geol. 288, 133-148.

Du, F.Q., 1983. The zonation of Xianghualing tin-polymetallic deposit and its prospecting significance. Geotecton. Metallog. 7(3), 239-247 (in Chinese with English abstract).

Du, G.W., Xu, K.F., 2001. Geochemical characteristics of "Sanjiang” area in eastern Tibet and their ore-prospecting significance. Geophys. Geochem. Explor. 25(6), 425-431 (in Chinese with English abstract).

Duan, J.L., Tang, J.X., Lin, B., 2016. Zinc and lead isotope signatures of the Zhaxikang Pb-Zn deposit, South Tibet: Implications for the source of the ore-forming metals. Ore Geol. Rev. 78, 58-68.

Egozcue, J.J., Pawlowsky-Glahn, V., Mateu-Figueras, G., Barcelo-Vidal, C., 2003. Isometric logratio transformations for compositional data analysis. Math. Geol. 35, 279-300.

Egozcue, J.J., Pawlowsky-Glahn, V., 2005. Groups of parts and their balances in compositional data analysis. Math. Geol. 37, 795-828.

Egozcue, J.J., Pawlowsky-Glahn, V., Gloor, G.B., 2018. Linear Association in Compositional Data Analysis. Aust. J. Stat. 47, 3-31.

Filzmoser, P., Hron, K., Reimann, C., 2012. Interpretation of multivariate outliers for compositional data. Comput. Geosci. 39, 77-85.

Frisch, W., Meschede, M., Blakey, R., 2011. Plate tectonics. Springer, Berlin, pp. 1-211.

Goldfarb, R.J., Groves, D.I., Gardoll, S., 2001. Orogenic gold and geologic time: a global synthesis. Ore Geol. Rev. 18, 1-75.

Gradstein, F.M., Ogg, J.G., Smith, A.G., 2005. A geologic time scale 2004. Cambridge University Press, Cambridge, pp. 1-589.

Groves, D.I., Goldfarb, R.J., Gebre-Mariam, M., 1998. Orogenic gold deposits: a proposed classification in the context of their crustal distribution and relationship to other gold deposit types. Ore Geol. Rev. 13, 7-27.

Huang, C.M., Zhao, Z.D., Zhu, D.C., Liu, D., Huang, Y., Dong, M.C., Hu, Z.C., Zheng, J.P., 2013. Geochemistry zircon $\mathrm{U}-\mathrm{Pb}$ chronology and $\mathrm{Hf}$ isotope of Luozha leucogranite, southern Tibet: Implication for petrogenesis. Acta Petrol. Sin. 29(11), 3689-3702 (in Chinese with English abstract).

Ji, W.Q., Wu, F.Y., Chung, S.L., Li, J.X., Liu, C.Z., 2009. Zircon U-Pb geochronology and Hf isotopic constraints on petrogenesis of the Gangdese batholith, southern Tibet. Chem. Geol. 262, 229-245.

Lee, J., Hacker, B., Wang, Y., 2004. Evolution of North Himalayan gneiss domes: Structural and metamorphic studies in Mabja Dome, southern Tibet. J. Struct. Geol. 26, 2297-2316.

Lee, J., McClelland, W., Wang, Y., Blythe, A., McWilliams, M., 2006. Oligocene-Miocene middle crustal flow in southern Tibet: Geochronology of Mabja Dome. Geol. Soc. London, Spec. Publ. 268, 445-469. the eastern Himalaya Orogen, Tibet, China: implications to palaeogeography and palaeotectonic evolution. Tectonophysics 666, 12-22.

Li, G.W., Liu, X.H., Alex, P., Wei, L.J., Liu, X.B., Huang, F.X., Zhou, X.J., 2010. In-situ detrital zircon geochronology and Hf isotopic analyses from Upper Triassic Tethys sequence strata. Earth Planet. Sci. Lett. 297, 461-470. 
Li, G.M., Zhang, L.K., Jiao, Y.J., Xia, X.B., Dong, S.L., Fu, J.G., Liang, W., Zhang, Z., Wu, J.Y., Dong, L., Huang, Y., 2017. First discovery and implications of Cuonadong superlarge Be-W-Sn polymetallic deposit in Himalayan metallogenic belt, souther Tibet. Miner. Deposits 36 (4), 1003-1008 (in Chinese with English abstract).

Li, G.Q., Cheng, W.B., Zhang, Y.M., Zhang, Y., Lv, P.R., Dai, H.Z., Zhang, X.G., Xia B.B., 2014. Geochemical characteristics and their geologic significance of the Lower Jurassic Ridang Formation host strata from the Zhaxikang Sb-Pb-Zn-Ag polymetallic ore-concentrated district, south Tibet. Bull. Mineral., Petrol. Geochem. 33(5), 598-608 (in Chinese with English abstract).

Lin, B., Tang, J.X., Zheng, W.B., Leng, Q.F., Yang, C., Tang, X.Q., Huang, Y., Wang, Y.Y., Tang, J.Y., 2014. Petrochemical features, zircon $\mathrm{U}-\mathrm{Pb}$ dating and $\mathrm{Hf}$ isotopic compositon of the rhyolite in Zhaxikang deposit, Southern Xizang (Tibet). Geol. Rev. 60(1), 178-189 (in Chinese with English abstract).

Lin, B., Tang, J.X., Zheng, W.B., Leng, Q.F., Lin, X., Wang, Y.Y., Meng, Z., Tang, P., Ding, S., Xu, Y.F., Yuan, M., 2016. Geochemical characteristics, age and genesis of Cuonadong leucogranite, Tibet. Acta Petrol. Mineral. 35(3), 391-406 (in Chinese with English abstract).

Liu, B.L., Guo, K., Li, C., Zhou, J., Liu, X.M., Wang, X.Q., Wang, L., 2020. Copper prospectivity in Tibet, China: Based on the identification of geochemical anomalies. Ore Geol. Rev., 120.

Liu, Y., Carranza, E.J.M., Zhou, K., Xia, Q., 2019. Compositional Balance Analysis: An Elegant Method of Geochemical Pattern Recognition and Anomaly Mapping for Mineral Exploration. Nat. Resour. Res. 28, $1269-1283$.

Liu, Y.Q., Ji, Q., Jiang, X.J., Kuang, H.W., Ji, S.A., Gao, L.F., Zhang, Z.G., Peng, N., Yuan, C.X., Wang, X.R., $\mathrm{Xu}, \mathrm{H} ., 2013$. UePb Zircon Ages of Early Cretaceous Volcanic Rocks in the Tethyan Himalaya at Yangzuoyong Co Lake, Nagarze, Southern Tibet, and Implications for the Jurassic/Cretaceous Boundary. Cretaceous Res. 40, 90-101.

Liu, Y.M., Dai, J.G., Wang, C.S., Li, H.A., Wang, Q., Zhang, L.L., 2020. Provenance and tectonic setting of Upper Triassic turbidites in the eastern Tethyan Himalaya: Implications for early-stage evolution of the NeoTethys. Earth-Sci. Rev. 200, 103030 Crossref.

Liu, Z.C., Wu, F.Y., Liu, X.C., Wang, J.G., Yin, R., Qiu, Z.L., Ji, W.Q., Yang, L., 2019. Mineralogical evidence for fractionation processes in the Himalayan leucogranites of the Ramba Dome, southern Tibet. Lithos 340$341,71-86$.

Ma, L., Kerr, A.C., Wang, Q., Jiang, Z.Q., Hu, W.L., 2018. Early Cretaceous ( 140 Ma) aluminous A-type granites in the Tethyan Himalaya, Tibet: Products of crust-mantle interaction during lithospheric extension. Lithos 300-301, 212-226.

McDermid, I., Aitchison, J., Davis, A., Harrison, T., Grove, M., 2002. The Zedong terrane: a Late Jurassic intra-oceanic magmatic arc within the Yarlung-Tsangpo Suture Zone, southeastern Tibet. Chem. Geol. 187, $267-277$.

McKinley, J.M., Hron, K., Grunsky, E.C., Reimann, C., de Caritat, P., Filzmoser, P., van den Boogaart, K.G., Tolosana-Delgado, R., 2016. The single component geochemical map: Fact or fiction? J. Geochem. Explor. $162,16-28$.

Meyers, P.A., Pratt, L.M., Nagy, B., 1992. Introduction to geochemistry of metalliferous black shales. Chem. Geol. 99, VII-XI.

Mitchell, A.H.G., Garson, M.S., 1976. Relationship at plate boundaries. Minerals Sci. Engng 8, 129-169. 
Mitchell, A.H.G., Garson, M.S., 1981. Mineral deposits and global tectonic settings. Academic Press, New York, pp. $1-405$.

Mo, X.X., Dong, G.C., Zhao, Z.D., Zhou, S., Wang, L.L., Qiu, R.Z., Zhang, F.Q., 2005. Spatial and temporal distribution and characteristics of granitoids in the Gangdese, Tibet and implication forcrustal growthand evolution. Geol. J. China Univ. 11, 281-290 (in Chinese with English abstract).

Pan, G.T., Ding, J., Yao, D.S., Wang, L.Q., 2004. Geological Map of the Tibetan Plateau and Adjacent Areas (1: 1,500,000). Chengdu Map Publishing House, Chengdu, China (English version).

Pawlowsky-Glahn, V., Buccianti, A., 2011. Compositional Data Analysis Theory and Applications. John Wiley \& Sons Ltd., London, pp. 1-372.

Pawlowsky-Glahn, V., Egozcue, J.J., Tolosana-Delgado, R., 2015. Modeling and analysis of compositional data. John Wiley \& Sons Ltd., London, pp. 1-205.

Pearson, K., 1897. Mathematical contributions to the theory of evolution.--On a form of spurious correlation which may arise when indices are used in the measurement of organs. Proc. R. Soc. Lond. 60, 359-367.

Petrik, A., Thiombane, M., Albanese, S., Lima, A., De Vivo, B., 2018. Source patterns of Zn, Pb, Cr and Ni potentially toxic elements (PTEs) through a compositional discrimination analysis: A case study on the Campanian topsoil data. Geoderma 331, 87-99.

Sun, X., Zheng, Y.Y., Wang, C.M., Zhao, Z.Y., Geng, X.B., 2016. Identifying geochemical anomalies associated with $\mathrm{Sb}-\mathrm{Au}-\mathrm{Pb}-\mathrm{Zn}-\mathrm{Ag}$ mineralization in North Himalaya, southern Tibet. Ore Geol. Rev. 73, 1-12.

Tang, J.X., Lang, X.H., Xie, F.W., Gao, Y.M., Li, Z.J., Huang, Y., Ding, F., Yang, H.H., Zhang, L., Wang, Q., Zhou, Y., 2015. Geological characteristics and genesis of the Jurassic No. I porphyry $\mathrm{Cu}-\mathrm{Au}$ deposit in the Xiongcun district, Gangdese porphyry copper belt, Tibet. Ore Geol. Rev. 70, 438-456.

Tibet Huayu Mining Co., Ltd., 2015. Prospectus for initial public offering of A shares. China Securities Regulatory Commission, Beijing, pp. 1-475 (in Chinese).

Tibetan Bureau of Geology and Mineral Resources, 1993. Lithostratigraphy of Xizang (Tibet) Autonomous Region. China University of Geosciences Press, Beijing, pp. 1-302 (in Chinese).

Van den Boogaart, K.G., Tolosana-Delgado, R., 2013. Analyzing Compositional Data with R. Springer, Heidelberg, pp. 1-253.

Wang, G.Q., Xia, B., 1987. The Norbusa ophiolite of Xizang(Tibet) and its tectonic significance. Geotecton. Metallog. 11(4), 349-362 (in Chinese with English abstract).

Wang, Y.Y., Tang, J.X., Zheng, W.B., Lin, B., Leng, Q.F., Chen, W., Ding, S., Song, J.L., Xu, Y.F., 2012. A tentative discussion on ore fabric and genesis of the Zhaxikang Zn-polymetallic deposit, Lhunze County, Tibet. Acta Geosci. Sin. 33(4), 681-692 (in Chinese with English abstract).

Wang, J.G., Wu, F.Y., Garzanti, E., Hu, X.M., Ji, W.Q., Liu, Z.C., Liu, X.C., 2016. Upper Triassic turbidites of the northern Tethyan Himalaya (Langjiexue Group): the terminal of a sediment-routing system sourced in the Gondwanide Orogen. Gondwana Res. 34, 84-98.

Wang, C.S., Liu, Z.F., Hebert, R., 2000. The Yarlung-Zangbo paleo-ophiolite, southern Tibet: implications for the dynamic evolution of the Yarlung-Zangbo Suture Zone. J. Asian Earth Sci. 18 (6), 651-661.

Wang, E., Kamp, P.J.J., Xu, G.Q., Hodges, K.V., Meng, K., Chen, L., Wang, G., Luo, H., 2015. Flexural bending of southern Tibet in a retro foreland setting. Sci. Rep. 5, 1-9.

728 Wang, X.Q., Zhang, Q., Zhou, G.H., 2007. National-Scale Geochemical Mapping Projects in China. Geostandards and Geoanalytical research 31, 311-320. 
Wang, W., Zhao, J., Cheng, Q., 2014. Mapping of Fe mineralization-associated geochemical signatures using logratio transformed stream sediment geochemical data in eastern Tianshan, China. J. Geochem. Explor. 141, $6-14$.

Webb, A.A., Yin, A., Dubey, C.S., 2013. U-Pb zircon geochronology of major lithologic units in the eastern Himalaya: implicationsfor the originand assemblyof Himalayan rocks. Geol. Soc. Am. Bull. 125(3-4), 499522.

Xie, X.J., Mu, X.Z., Ren, T.X., 1997. Geochemical mapping in China. J. Geochem. Explor. 60(1), 99-113.

Xie, X.J., Wang, X.Q., Zhang, Q., Zhou, G.H., Cheng, H., Liu, D.W., Cheng, Z.Z., Xu, S.F., 2008. Multi-scale geochemical mapping in China. Geochem.: Explor., Environ., Anal. 8, 333-341.

Xu, Z.Q., Yang, J.S., Liang, F.H., Qi, X.X., Liu, F.L., Zeng, L.S., Liu, D.Y., Li, H.B., Wu, C.L., Shi, R.D., Chen, S.Y., 2005. Pan-African and early Paleozoic orogenic events in the Himalaya terrane: Inference from SHRIMP U-Pb zircon ages. Acta Petrol. Sin. 21(1), 1-12 (in Chinese with English abstract).

Yang, W.C., Xie, X.J., 2017. Geochemical mapping in Xizang(Tibet) and its significances. Geol. Rev. 63(2), 269-276 (in Chinese with English abstract).

Yang, Y.H., Zeng, L., Deng, F., Hu, J.Z., 2018. Geological characteristics and mineralizaiton potential of chromite resources in China. Earth Sci. Front. 25(3), 138-147 (in Chinese with English abstract).

Yang, Z.S., Hou, Z.Q., Gao, W., Wang, H.P., Li, Z.Q., Meng, X.J., Qu, X.M., 2006. Metallogenic characteristics and genetic model of antimony and gold deposits in South Tibetan detachment system. Acta Geol. Sin. 80(9), 1377-1391 (in Chinese with English abstract).

Yang, Z.S., Hou, Z.Q., Meng, X.J., Liu, Y.C., Fei, H.C., Tain, S.H., Li, Z.Q., Gao, W., 2009. Post-collisional Sb and Au mineralization related to the South Tibetan detachment system, Himalayan orogeny. Ore Geol. Rev. 36, 194-212.

Yang, T.S., Ma, Y.M., Bian, W.W., Jin, J.J., Zhang, S.H., Wu, H.C., Li, H.Y., Yang, Z.Y., Ding, J.K., 2015. Paleomagnetic results from the Early Cretaceous Lakang Formation lavas: Constraints on the paleolatitude of the Tethyan Himalaya and the India-Asia collision. Earth Planet. Sci. Lett. 428, 120-133.

Yang, C., Tang, J.X., Zheng, W.B., Lin, B., Wang, L.Q., Duan, J.L., Kang, H.R., 2014. Study on zircon U-Pb geochronology and petrogeochemistry of diabase in Zhaxikang Zn-polymetallic deposit, Southern Tibet. Nonferrous Met. (Mine Sect.) 66(5), 30-37 (in Chinese with English abstract).

Yin, A., Harrison, T.M., Murphy, M.A., Grove, M., Nie, S., Ryerson, F.J., Wang, X., Chen, Z., 1999. Tertiary deformation history of southeastern and southwestern Tibet during the Indo-Asian collision. Geol. Soc. Am. Bull. 111, 1644-1664.

Yin, A., Harrison, T.M., 2000. Geologic evolution of the Himalayan-Tibetan Orogen. Annu. Rev. Earth Planet. Sci. 28(1), 211-284.

Yin, A., 2006. Cenozoic tectonic evolution of the Himalayan orogen as constrained by along-strike variation of structural geometry, exhumation history, and foreland sedimentation. Earth-Sci. Rev. 76, 1-131.

Zeng, L.S., Gao, L.E., Xie, K.J., Jing, L.Z., 2011. Mid-Eocene high Sr/Y granitesinthe Northern Himalayan Gneiss Domes: Melting thickened lower continental crust. Earth Planet. Sci. Lett. 303, 251-266.

Zhai, Y.S., Yao, S.Z., Cai, K.Q., 2011. Mineral deposits (3rd Edition). Geological Publishing House, Beijing, pp. 68-69 (in Chinese).

Zhai, W., Sun, X.M., Yi, J.Z., Zhang, X.G., Mo, R.W., Zhou, F., Wei, H.X., Zeng, Q.G., 2014. Geology, geochemistry, and genesis of orogenic gold-antimony mineralization in the Himalayan Orogen, South Tibet, China. Ore Geol. Rev. 58, 68-90. 
Zhang, J.J., Santosh, M., Wang, X.X., Guo, L., Yang, X.Y., Zhang, B., 2012. Tectonics of the northern Himalaya since the India-Asia collision. Gondwana Res. 21, 939-960.

Zhang, C.K., Li, X.H., Mattern, F., Mao, G.Z., Zeng, Q.G., Xu, W.L., 2015. Deposystem architectures and lithofacies of a submarine fan-dominated deep sea succession in an orogen: a case study from the Upper Triassic Langjiexue Group of southern Tibet. J. Asian Earth Sci. 111, 222-243.

Zhang, X., Deng, X.G., Yang, Z.S., Hou, Z.Q., Zheng, Y.C., Liu, Y.C., Zhao, X.Y., Xu, B., Pei, Y.R., Zhou, J.S., Zhao, M., Yuan, J.F., 2017. Genesis of the gold deposit in the Indus-Yarlung Tsangpo suture zone, Southern Tibet: Evidence from geological and geochemical data. Acta Geol. Sin. (English Edition) 91(3), 947-970.

Zhang, J.F., Zheng, Y.Y., Zhang, G.Y., Gao, S.B., Ye, X.R., Zhang, Z., Liu, M.Y., Li, J.Q., 2010. Genesis of Zhaxikang Pb-Zn-Sb-Ag deposit in Northern Himalaya: Constraints from multi-isotope geochemistry. Earth Sci. J. China Univ. Geosci. 35(6), 1000-1010 (in Chinese with English abstract).

Zhang, Z., Tang, J.X., Lin, B., Zheng, W.B., Lin, X., Tang, X.Q., Gao, Y.M., Wang, Y.Y., Yang, H.H., Huang, J., 2016. Geochemical characteristics of trace elements of sphalerite in the Zhaxikang deposit, Southern Tibet, and their geological significances. Bull. Mineral., Petrol. Geochem. 35(6), 1203-1216 (in Chinese with English abstract).

Zheng, Y.Y., Duo, J., Ma, G.T., Chen, J., Dai, F.H., 2007. Mineralizaiton characteristics, discovery and age restriction of Chalapu hardrock gold deposit, Southern Tibet. Earth Sci. J. China Univ. Geosci. 32(2), 185193 (in Chinese with English abstract).

Zheng, Y.Y., Liu, M.Y., Sun, X., Yuan, E.H., Tian, L.M., Zheng, H.T., Zhang, G.Y., Zhang, L.H., 2012. Type, discovery process and significance of Zhaxikang antimony polymetallic ore deposit, Tibet. Earth Sci. J. China Univ. Geosci. 37(5), 1003-1014 (in Chinese with English abstract).

Zheng, Y.Y., Sun, X., Gao, S.B., Wang, C.M., Zhao, Z.Y., Wu, S., Li, J.D., Wu, X., 2014. Analysis of stream sediment data for exploring the Zhunuo porphyry $\mathrm{Cu}$ deposit, southern Tibet. J. Geochem. Explor. 143, 1930.

Zheng, W.B., Ding, S., Leng, Q.F., Wang, Y.Y., Lin, B., 2017. Petrogeochemical characteristics of a typical crosssection in the Zhaxikang ore district of Tibet and their geological significance. Geol. Explor. 53(1), 97-108 (in Chinese with English abstract).

Zhong, L.F., Xia, B., Zhang, Y.Q., Wang, R., Wei, D.L., Yang, Z.Q., 2006. SHRIMP age deter-mination of Dolerite in Luobusa ophiolite, southern Xizang (Tibet). Geol. Rev. 52, 224-229.

Zhu, D.C., Pan, G.T., Mo, X.X., Liao, Z.L., Jiang, X.S., Wang, L.Q., Zhao, Z.D., 2007. Petrogenesis of volcanic rocks in the Sangxiu Formation, central segment of Tethyan Himalayas: a probable example of plume-lithosphere interaction. J. Asian Earth Sci. 29, 320-335.

Zhu, D.C., Mo, X.X., Pan, G.T., Zhao, Z.D., Dong, G.C., Shi, Y.R., Liao, Z.L., Wang, L.Q., Zhou, C.Y., 2008. Petrogenesis of the earliest early cretaceous basalts and associated diabases from Cona area, eastern Tethyan Himalaya in south Tibet: interaction between the incubating Kerguelen plume and eastern Greater India lithosphere. Lithos 100, 147-173.

Zhu, D.C., Chung, S.L., Mo, X.X., Zhao, Z.D., Niu, Y., Song, B., Yang, Y.-H., 2009. The 132 Ma Comei-Bunbury large igneous province: remnants identified in present-day southeastern Tibet and southwestern Australia. Geology 37, 583-586.

Zhu, L.K., Gu, X.X., Li, G.Q., Zhang, Y.M., Cheng, W.B., Bian, X.D., 2012. Fluid inclusions in the Zhaxikang $\mathrm{Pb}-\mathrm{Zn}$-Sb polymetallic deposit, South Tibet, and its geological significance. Geoscience 26(3), 453-463(in Chinese with English abstract). 


\section{Figure captions:}

Fig. 1. (a) Tectonic sketch map showing location of the study area (after Pan et al., 2004; Yin et al., 2000). JS, Jinshajiang suture; LSS, Longmucuo-Shuanghu suture; BNS, Bangonghu-Nujiang suture; IYZS, Indus-Yarlung Zangbo suture; STDS, South Tibetan detachment system; MCT, Main Central Thrust; MBT, Main Boundary Thrust; ALT, Altyn Tagh fault; KF, Kunlun fault; KLF, Karakoram fault; JF, Jiali fault. TH, Tethys Himalaya; HH, Higher Himalaya; LH, Lesser Himalaya. (b) Generalized geological and deposits distribution map of the study area (after Pan et al., 2004). LQS, Lazi-Qiongduojiang suture; LF, Lhunze fault; LCF, Lhozhag-Cuonadong fault. Chromite deposits: LBS, Luobusha; XKS, Xiangkashan; KJL, Kangjinla. Au deposits: NZ, Nianzha; SHL, Shengla; KB, Kangbugunba; ND, Naodong; HW, Hawong; SL, Sheli; BB, Bangbu; XG, Xigong; MD, Muda; CLP, Chalapu. Sbpolymetallic deposits: ZXK, Zhaxikang; KY, Keyue; YF, Yufeng; GD, Gudui; MZL, Mazhala; ZG, Zhegu; YR, Yongri; RL, Rangla; CB, Cheqiongzhuobu.

Fig. 2. (a) Generalized geological map of Luobusha ore district. (b) Typical cross-section of Luobusha deposit.

Fig. 3. (a) Generalized geological map of Nianzha ore district. (b) Typical cross-section of Nianzha deposit.

Fig. 4. (a) Generalized geological map of Zhaxikang ore district. (b) Typical cross-section of Zhaxikang deposit.

Fig. 5. Geological information overlapped with ilr balances map. (a) (i) correspond to the nine balances of B1 B9, respectively.

Fig. 6. Metallogenic prediction model of the study area. 


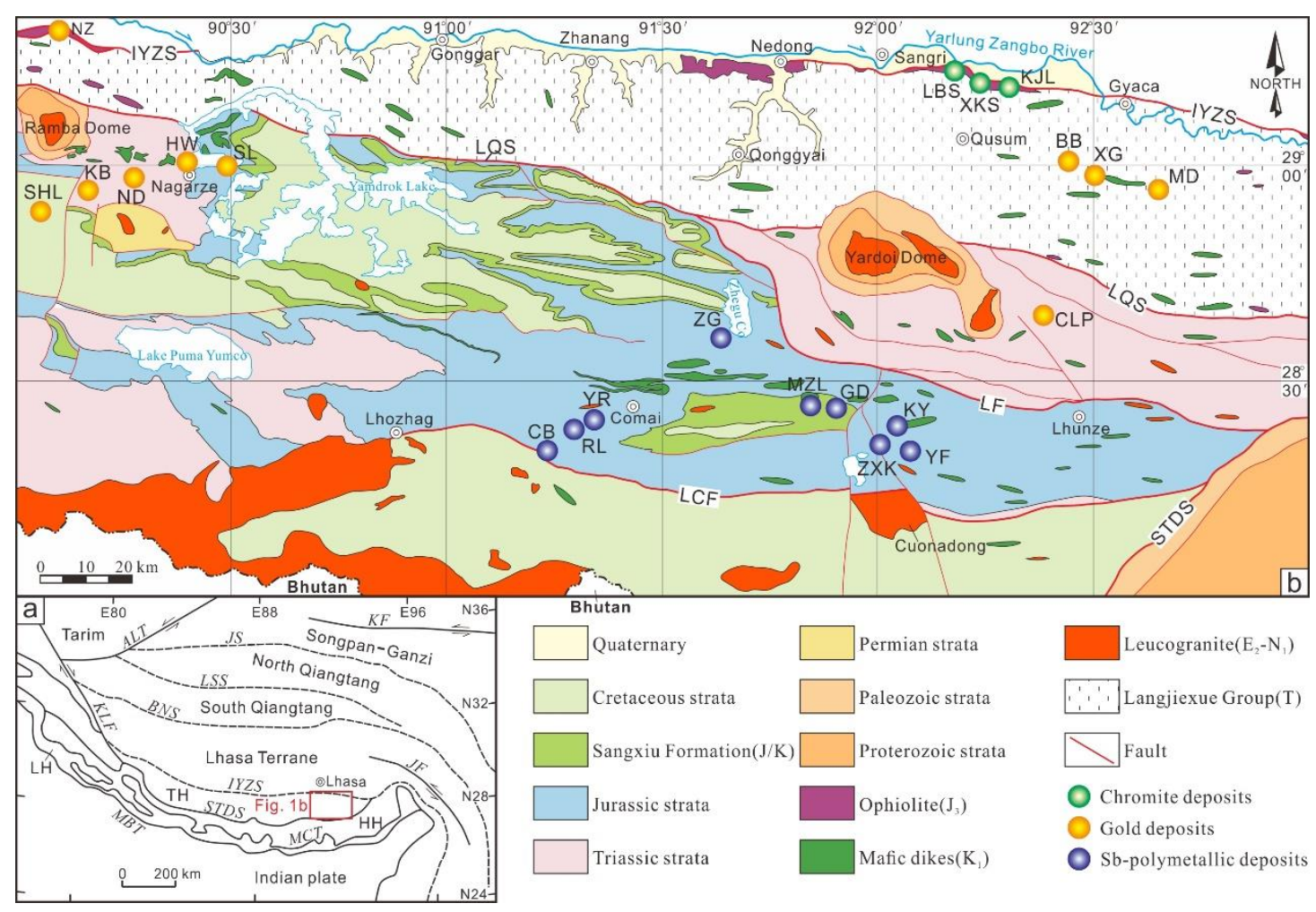




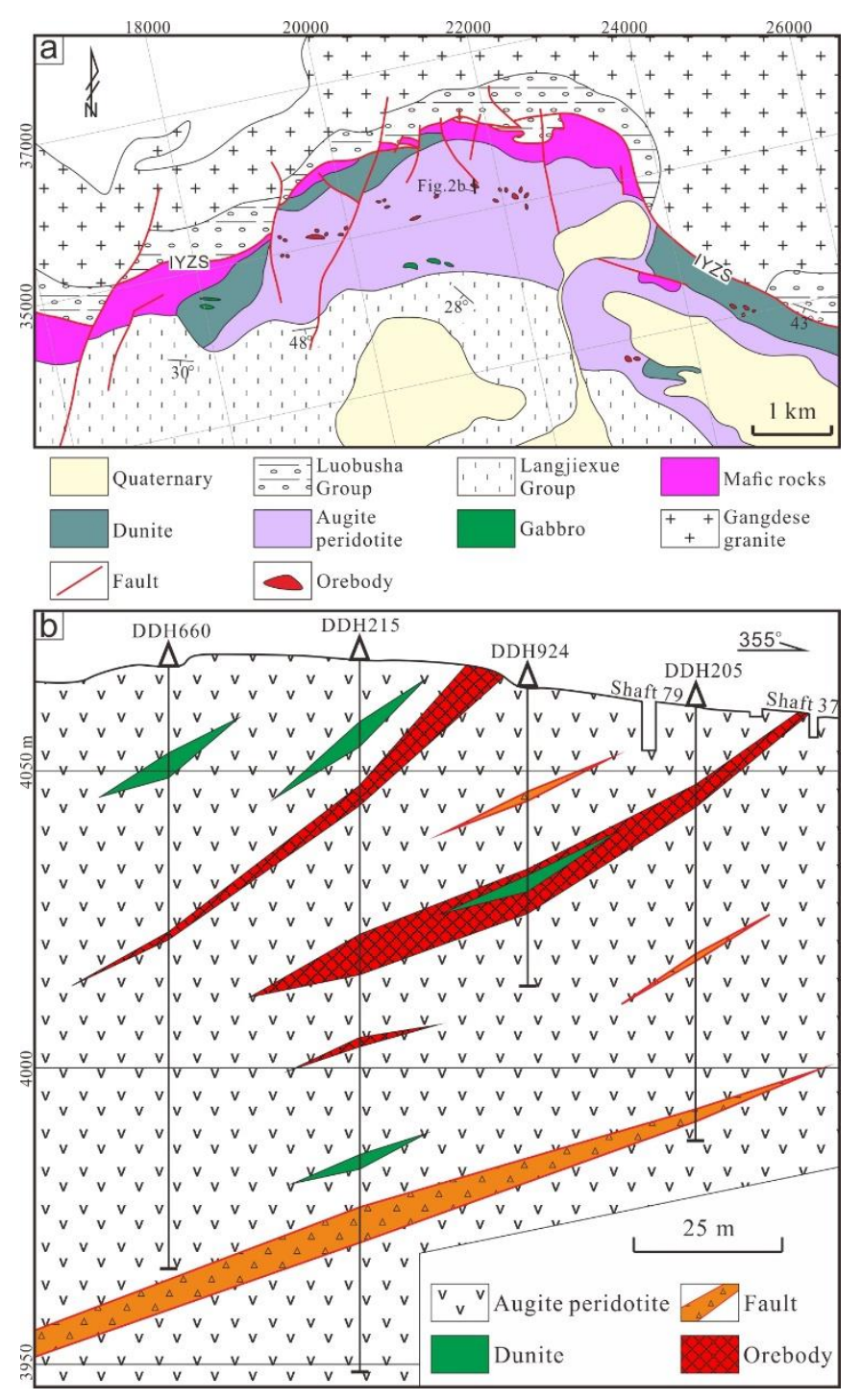




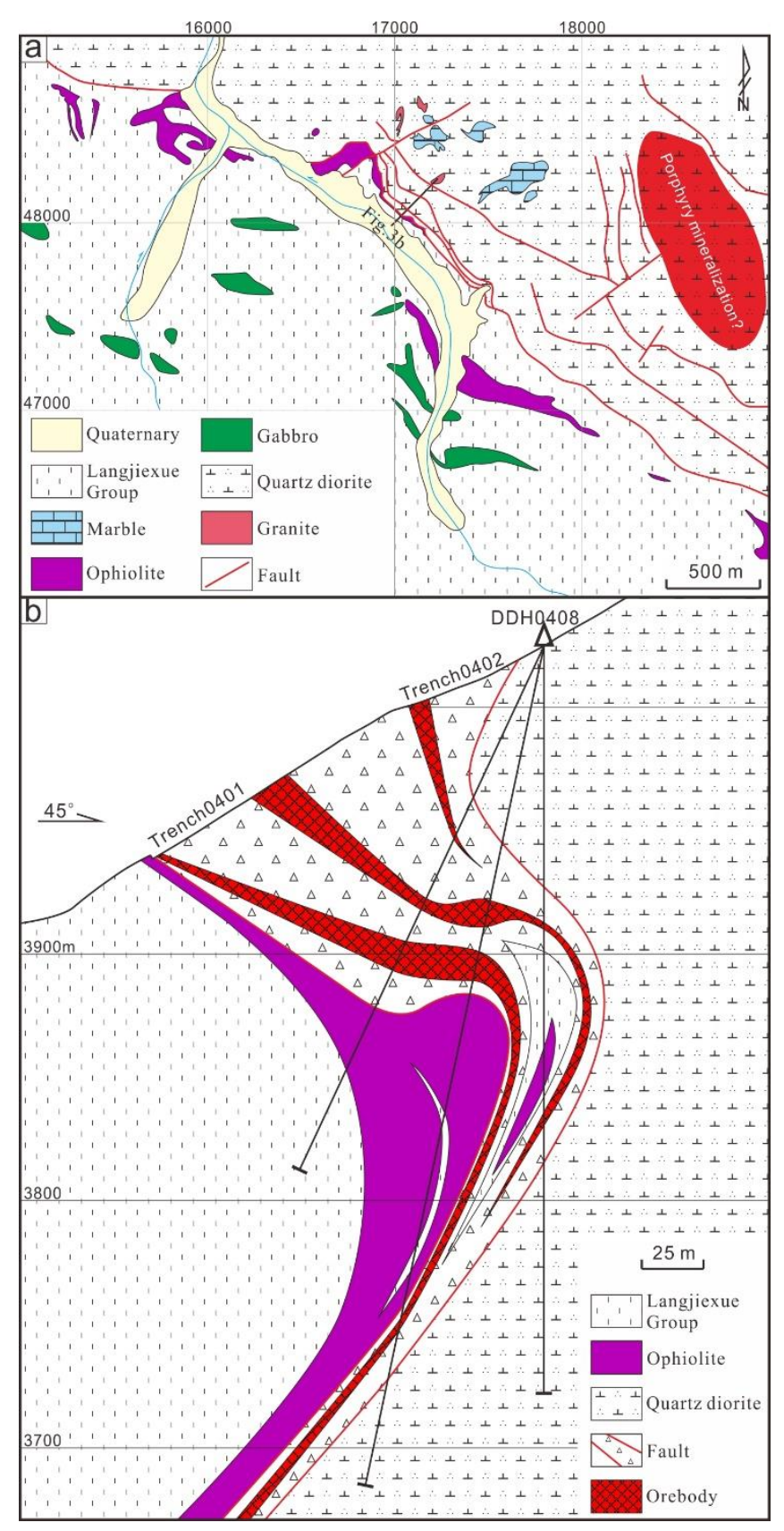




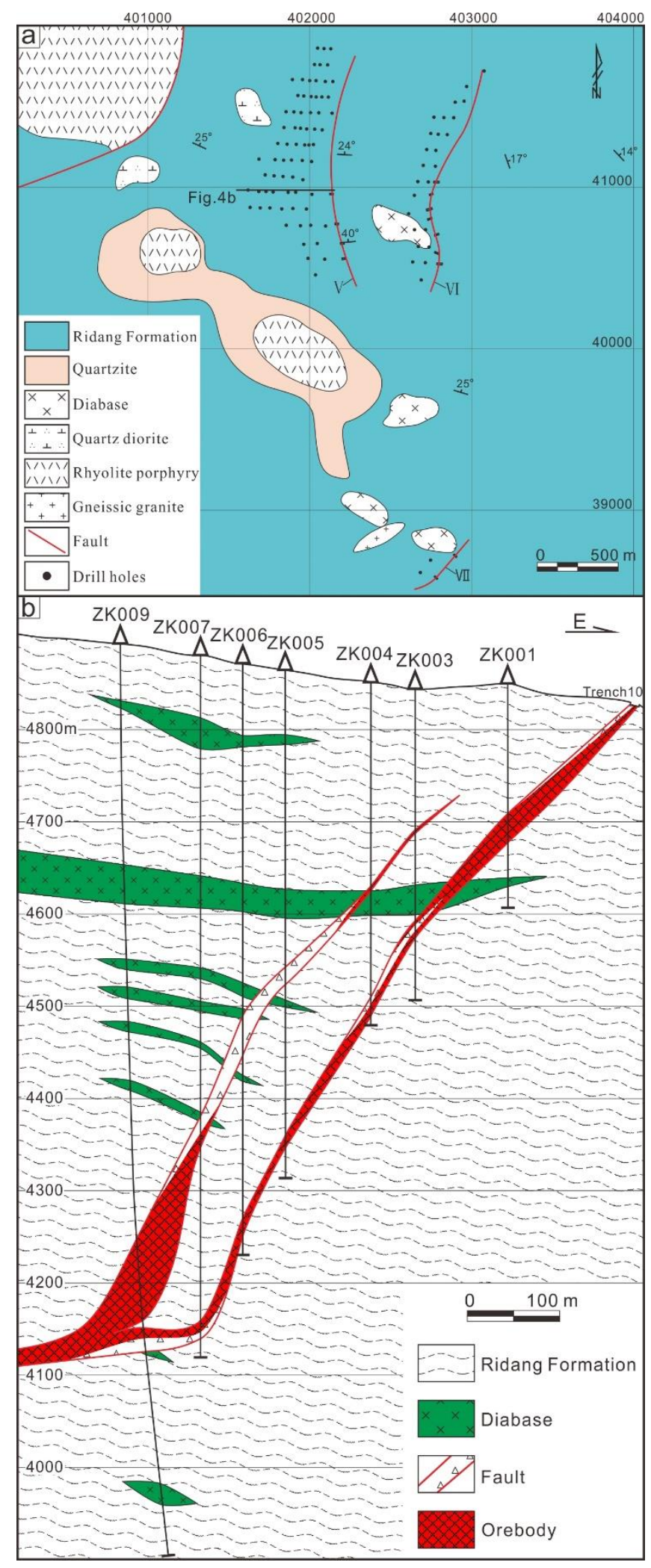




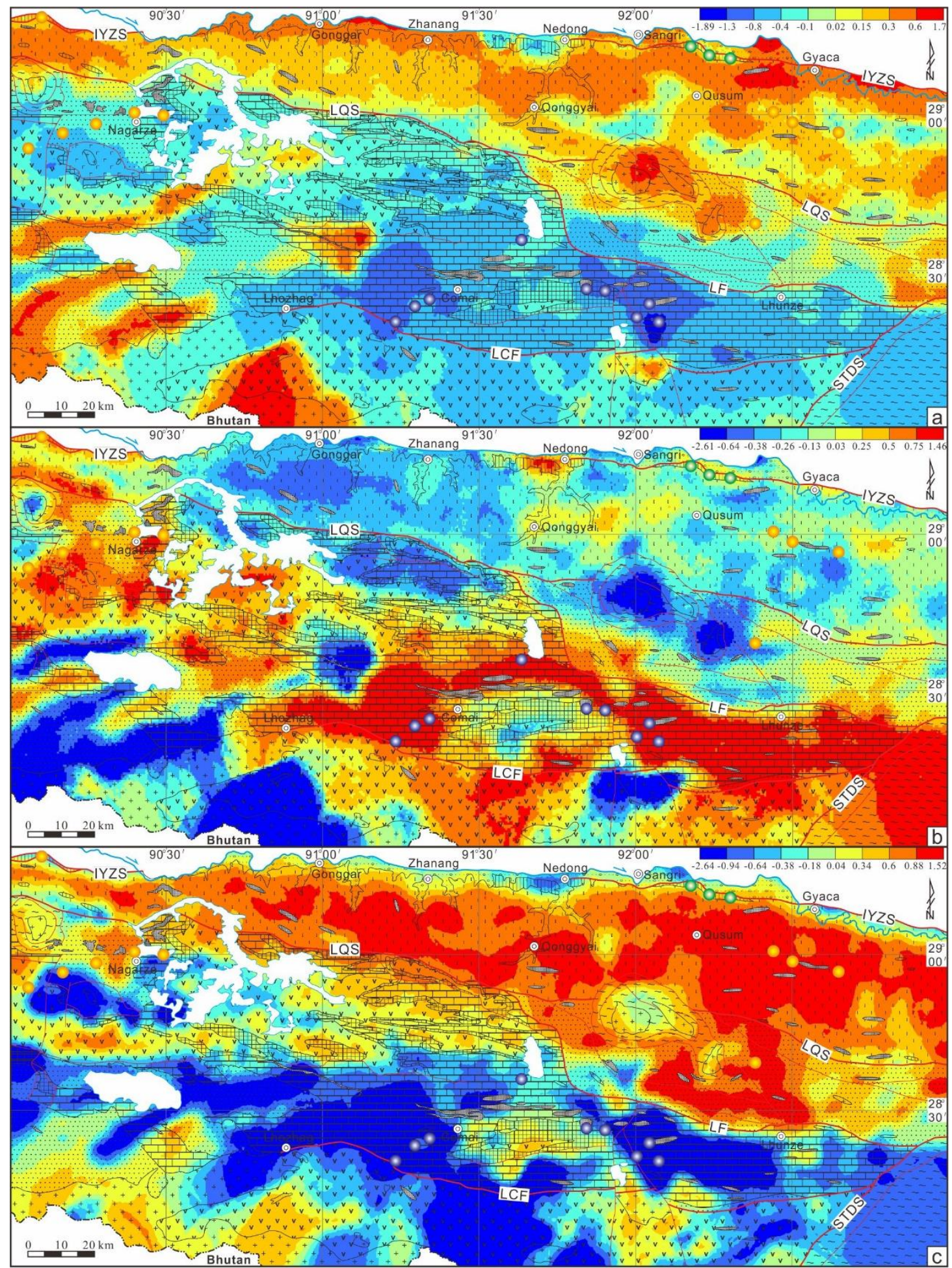

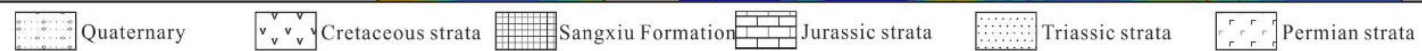

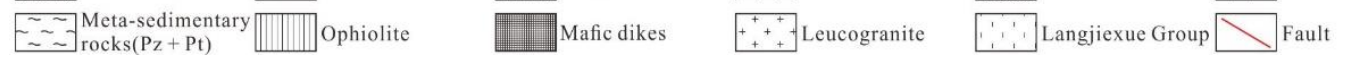




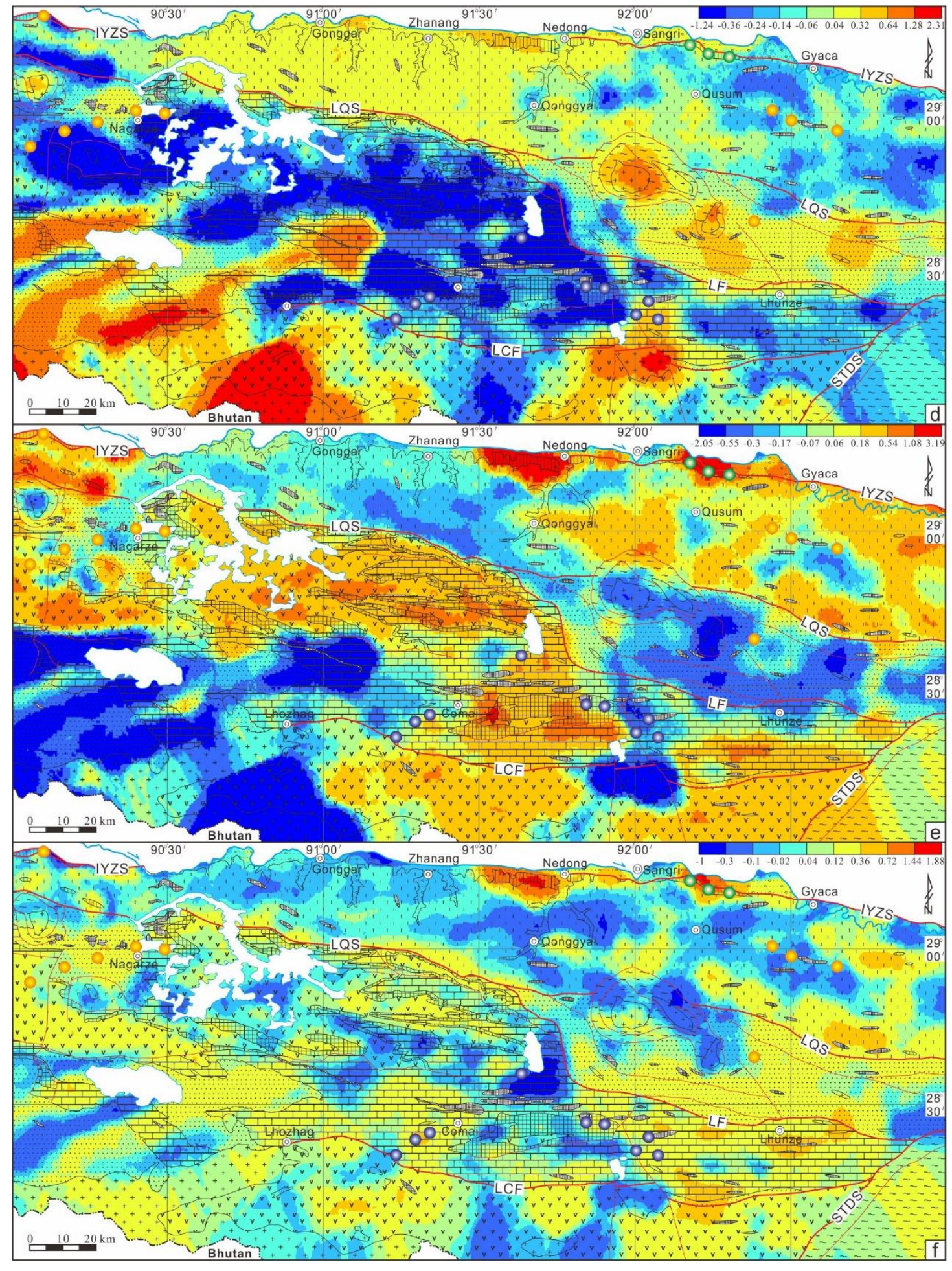




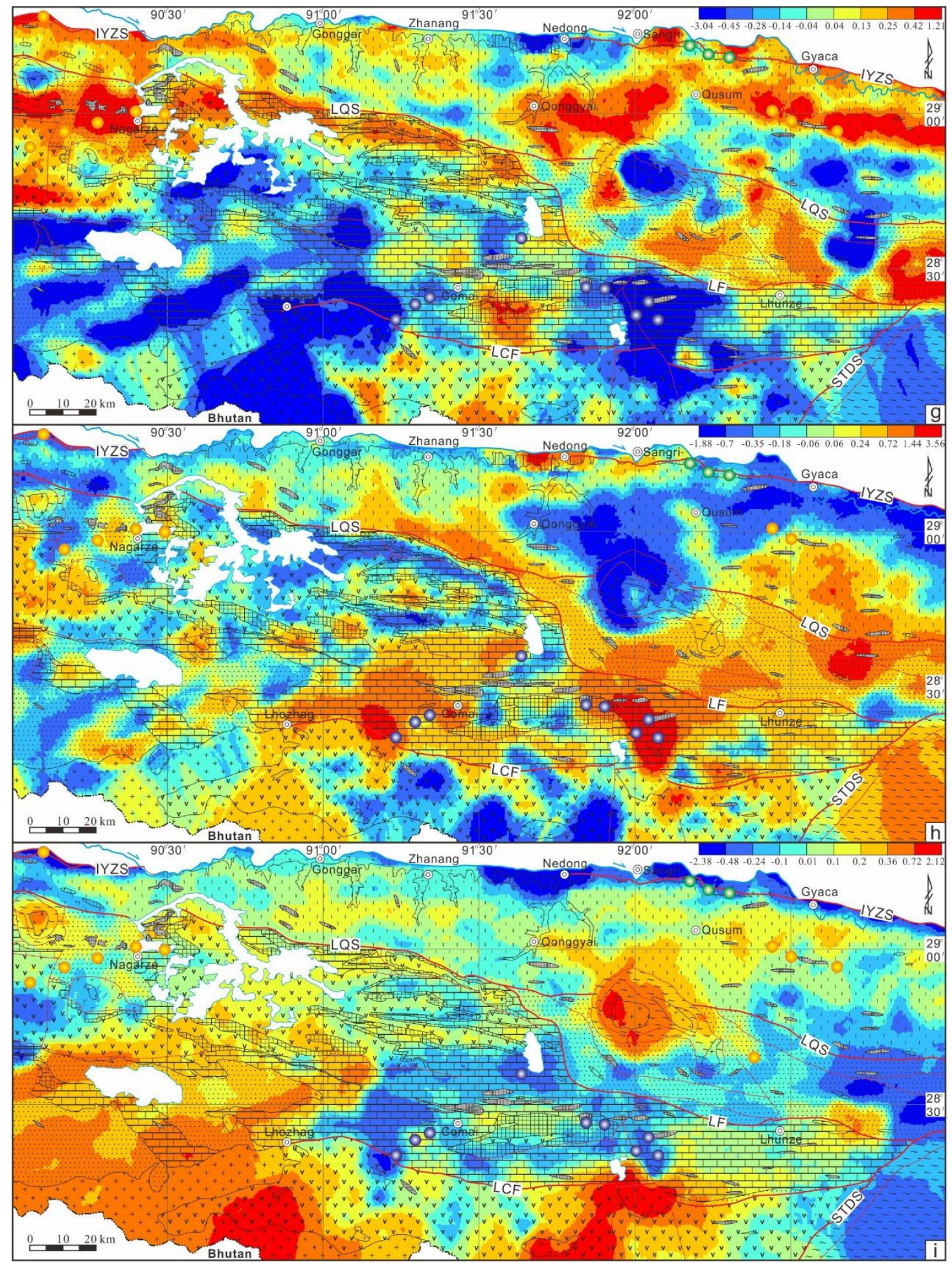




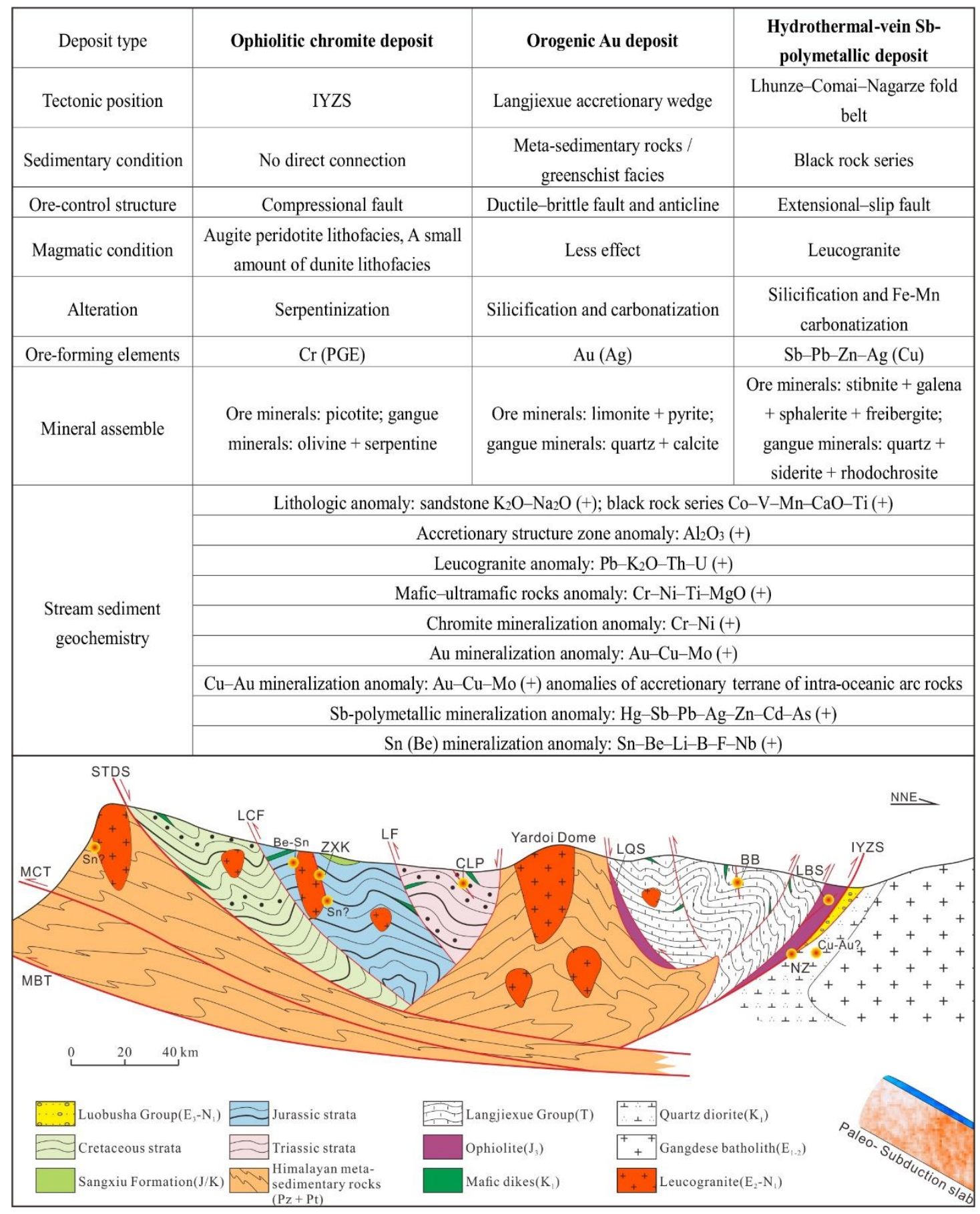


Click here to access/download

Table Table 1.docx

Table 
No Conflict of Interest

Conflict of Interest

No Conflict of Interest

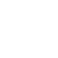

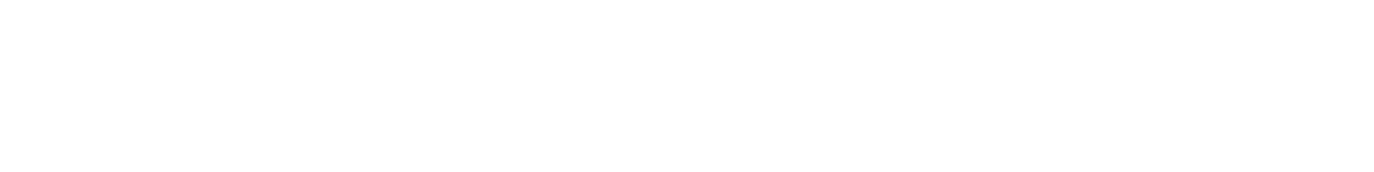
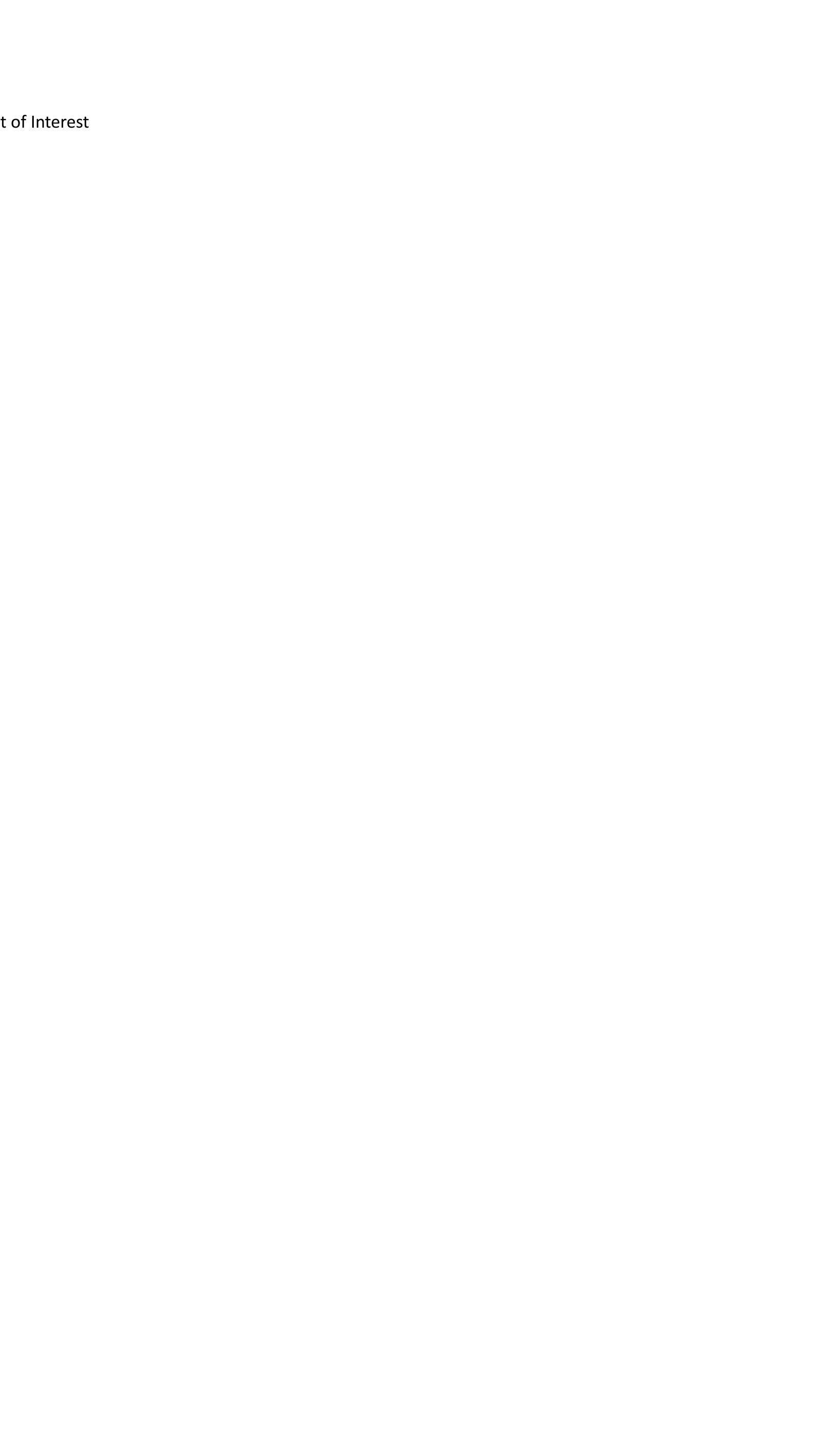